\title{
Profile of Contributors to the American Political Science Review, 2010
}

\author{
Amadu Jacky Kaba ${ }^{1}$ \\ ${ }^{1}$ Department of Sociology, Anthropology and Social Work, Seton Hall University, South Orange, New Jersey, \\ USA
}

Correspondence: Amadu Jacky Kaba, Department of Sociology, Anthropology and Social Work, Seton Hall University, South Orange, New Jersey, USA. E-mail: kabaamad@shu.edu

Received: March 22, 2013 Accepted: March 29, 2013 Online Published: May 30, 2013

doi:10.5539/jpl.v6n2p54 URL: http://dx.doi.org/10.5539/jpl.v6n2p54

\begin{abstract}
This study examines the profile of contributors of full-length articles to the American Political Science Review $(A P S R)$ in 2010. Of the 79 different contributors, almost 9 (86.1\%) out of every 10 are men. Whites accounted for over 9 (93.7\%) out of every 10 contributors. Full professors accounted for 35\%, the highest rate, with assistant professors accounting for 31 percent. Yale University, Harvard University, University of Illinois-Champaign, Florida State University, Massachusetts Institute of Technology, University of California-San Diego, and the University of Chicago, all employ 3 or more of these contributors. Almost $94 \%$ of the contributors have a Ph.D. Almost $89 \%$ of the contributors earned their terminal or highest degrees in political science/government. Harvard University, the University of Chicago, the University of Rochester, the University of California-Berkeley, and Duke University, all conferred 4 or more terminal or highest degrees to these contributors. The study presents explanations for these results, focusing on the underrepresentation of women and minorities.
\end{abstract}

Keywords: human progress, gender, race, university rankings, endowments, elitism

\section{Introduction}

By 2013, among the three sister social science disciplines of economics, political science and sociology, political science is now second to economics in terms of the total number of scholarly publications examining various aspects of their disciplines. A substantial proportion of these scholarly articles either focus only on the American Political Science Review (APSR) or along with other political science journals, or comparison of APSR with the top journals in economics, sociology and other journals in and outside of the social sciences. With its first issue published in 1906, the APSR has become the discipline's top ranked journal and one of the top ranked journals in and outside of the social sciences. Others have claimed that the APSR is the top ranked political science journal in the world. Scholars who publish in the APSR can be employed at the top ranked colleges and universities not just in the United States, but also the world. They can also get promoted and have the opportunity to earn higher salaries and benefits. They are among the scholars who get very large sums of research grants from governments or foundations. They have substantial influence over the U.S. federal government and other governments in the world. The APSR like the top economics journal in the U.S., the American Economic Review $(A E R)$ are known as international journals, which means that students and scholars, policy makers and other elites in the U.S. and abroad tend to read them and the authors that publish in them are from all over the world. So once one publish an article in the APSR, he or she can become internationally known, which benefits the institutions that employ them (Ballard \& Mitchell, 1998; Breuning \& Sanders, 2007; De Rond \& Miller, 2005; Evans \& Moulder, 2011; Finifter, 1998; Fisher et al., 1998; Garand et al., 2009; Garand \& Graddy, 1999; Garand \& Giles, 2003; Grofman, 2009; Hesli \& Lee, 2011; Marshall \& Rothgeb, Jr. 2011; Miller \& Tien, 1996; Plümper, 2007; Rogowski, 2012; Schmidt \& Chingos, 2007, p. 523; Polsky, 2007; Sigelman, 2006; Tang \& Chamberlain, 2003).

Fisher et al. (1998) note of the efforts of political scientists to study various aspects of their profession: "Political scientists have a tradition of reflecting on the evolution and state of their discipline. Numerous studies have examined rankings of departments ... graduate programs... journals ... and citation rates.... The status of women in the profession-ascertained by, for example, counting the number of Ph.D.s granted over time-has also become a subject of study..." (p. 847). Garand and Giles (2003) point out that:

"Along with books, scholarly journals constitute the primary media through which political scientists communicate the results of their research to their discipline. However, not all journals 
are created equal. There is a hierarchy of scholarly journals in political science, with some journals being highly respected and others less so. Articles published in the most highly regarded journals presumably go through a rigorous process of peer review and a competition for scarce space that results in high rejection rates and a high likelihood of quality" (p. 293).

According to Plümper (2007):

"Most articles published in refereed journals are never cited, some articles attract a few cites, and a few articles become 'classics'. The vast majority of these classic articles are published by a handful of the leading journals. Since 1990, five journals, the American Political Science Review (APSR), International Organization (IO), International Security, Foreign Affairs, and the Journal of Peace Research (JPR), have published articles which were cited more than 250 times in SSCI journals.... With eighteen journals having published the seventy-one articles that attracted over 100 citations, more than half of these articles have appeared in the three leading political science journals APSR (22), American Journal of Political Science (AJPS) (10), and IO (9)" (p. 41).

Sigelman (2006) writes of the "coevolution" of the APSR and American Political Science and notes of the APSR that:

"Over time, the challenges of editing the Review changed as its core constituency, academicians, grew more numerous and as more of them came to regard themselves as producers as well as consumers of research.... With submissions mounting, successive editors had to begin rejecting papers on more than an occasional basis. By the end of his quarter-century at the helm of the Review, [Frederic A] Ogg claimed to be accepting "not more than one article in four" ... and by the end of the Review's first century Ogg's successors were accepting only about 1 in 10 or 12 . As the Review became more selective, it came to be regarded as the showcase for the best that the discipline had to offer, solidifying its status as the discipline's "flagship" journal.... It became a-even the-primary gatekeeper for political science research, a role that many have rued... but virtually everyone has acknowledged. As a consequence, "virtually all practicing political scientists have been oriented by this publication . . . , even when they disliked [it]..." (pp. 463-464).

According to Miller and Tien (1996):

"APSR is the leading political science journal in the United States... APSR is substantively broad based, peer reviewed, high quality, widely circulated (16,000 subscriptions), and has an acceptance rate of about $10 \%$. An article published in APSR indicates research of considerable merit and significance for the entire field of political science. Given the prestige and difficulty associated with publishing in APSR, we argue that accomplishing this task a number of times is a feat that should be recognized" (Quoted in "Why an Interest in Who Publishes in APSR? Section of article).

In a comparative study of political science journals in the United States, Canada and the United Kingdom, Garand et al. (2009) write:

"What do we know about how political scientists evaluate scholarly journals in the discipline? First, most of the work on subjective journal evaluations has been conducted in the United States, and there is a discernible pattern of journal rankings among American political scientists. Some journals are regularly awarded with elite status; these are journals that are familiar to high proportions of political scientists and receive high marks for the rigor and quality of research that they publish. Other journals are targeted to more specialized audiences (and hence are not broadly familiar to political scientists), are perceived as less rigorous in their scholarly standards, or both, and these journals typically receive less favorable evaluations from American political scientists" (p.696).

For all of the variables (including impact and familiarity) examined in the study by Garand et al. (2009), the APSR is ranked higher than all of the other journals (pp. 699-713). Pertaining to the difficulty of publishing a full length article in the APSR, Finifter (1998) notes of the journal "...publishing about $8 \%$ of manuscripts received" (p. 899). According to Rogowski (2012) the acceptance rate by the APSR in 2011 was 7 percent, and that there were 799 submissions in 2010-2011, including 685 new submissions (p. 327).

As a result of the information just presented above, it is important to examine (even if only for a single year) the contributors to the APSR in 2010 so that we can learn about their demographics and other important variables. 
This article is the last of a series of three studies focusing on three sister disciplines in the social sciences, economics, political science, and sociology, examining various types of background information or profile of contributors of full-length articles to the top journal in each discipline: the American Economic Review (AER) American Political Science Review (APSR), and the American Sociological Review (ASR) in 2010. The first focuses on the profile of contributors to all five issues of the $A E R$ in 2010 (Kaba, 2013a). The second study focuses on the profile of contributors to all six issues of the $A S R$ in 2010, and compared with all of the variables examined in the studies focusing on the contributors to the 2010 AER and APSR (Kaba, 2013b). My original research goal was to do one large study examining the profile of contributors of full length articles to all three journals in 2010, but from the start of the project in early January 2012 to October 2012 when I finished compiling and computing the data (after over 2,500 hours as the only or sole author), I realized that it was too large for one study, so I decided to break it into three different studies, each focusing on each journal. For example, the study on the contributors to the $A E R$ in 2010 is 140 pages double spaced.

Why focus on these three disciplines? First, there have been many useful scholarly publications partly or fully focusing on all three of these disciplines or any two of them (Agarwala \& Teitelbaum, 2010; DiFuccia et al., 2007, p. 4; Jacobs, 2007; Paxton \& Bollen, 2003; Willoughby, 1904, p. 107). Second, the AER is regarded as the top journal in economics (Heck, 1993, p. 164), the ASR is regarded as the top journal in sociology (Jacobs, 2005, p.1), and there have also been useful scholarly publications focusing more on all three of them, any two of them, or any of them in addition to other social science journals (Butler et al., 2008; Fisher et al., 1998, p. 848; Garand \& Giles, 2003, p. 298; Jacobs, 2007; McCormick \& Rice, 2001, pp. 675-676 ).

The purpose of this current study, like the other two previous ones is to introduce these contributors of full length articles to the general public so that people can have an understanding of their profile or background. This study is also to introduce these contributors and their works to the students who enroll in my courses and hope that some of these students will aspire to earn doctorates in these disciplines and make similar contributions. Another purpose of this study is to present an account of the status of women and minorities, especially Blacks in the political science discipline. The study begins with a methodology, data availability and limitations section. Next the section focusing on the findings and analysis of compiled and computed data is presented. Finally, a discussion and conclusion section providing some explanations as to why some of the results turned out the way they did, with a focus on the gender and racial gaps observed in the study are presented.

\section{Methodology, Data Availability and Limitations of Study}

The information in this methodology section is similar to those in both of the sister studies on the 2010 American Economic Review (Kaba, 2013a) and the American Sociological Review (Kaba, 2013b), due to the fact that as noted above they all started as one study, which became too large and had to be broken down into three separate studies.

For this current study of the contributors of full length articles (also see Miller \& Tien, 1996, "Data Collection" Section of article) to all four issues of the 2010 American Political Science Review, I created over a dozen variables. They are: gender/sex; racial/cultural background; job title/position; institution/organization of employment; department/unit of employment; U.S. and world regions of employment; U.S. state/country of employment; numbers and types of highest or terminal degrees earned; academic major or field of earned highest or terminal degree; institution of graduation with highest or terminal degree; U.S. state/country where earned highest or terminal degrees institutions are located; U.S. and world region where earned highest or terminal degree institutions are located; and year of highest or terminal degree attainment.

There are 79 different contributors of full-length articles in all four issues of the 2010 American Political Science Review. Two contributors published two articles each, but I only counted each one of them once to get the 79 total instead of 81 . So no one of the 79 contributors is counted more than one time.

For the gender/sex variable, I searched the internet and matched the photo of contributors. In instances where there was no photograph of a contributor available, especially in the instance where one cannot tell a name that can be both male or female (androgynous names), I searched for information describing the contributor as he or she (also see Breuning \& Sanders, 2007, p. 348; Fisher et al., 1998, p. 849).

For the Race variable, I utilized the racial classifications of groups in the United States, but for any scholar or professor with Native American and White ancestry (such as Spanish ancestry from Spain or European), I classified her or him as Mestizo. Burchard et al. (2005) claim that “...intermarriage between Spanish Christians and Native Americans, the progeny of which were called Mestizos..." (p. 2162). Pertaining to who is White, Black and Asian in the United States, individuals with blood ancestry from Europe and selected Asian nations and regions, such as the Middle East (such as Arab nations including those in North Africa, Israel, Iran, Turkey, 
Central Asia etc.) are categorized as White, while anyone with visible Black African heritage or blood is Black. Also, individuals from Asian nations such as China, North and South Korea, Bangladesh, Japan, India, Pakistan, Sri Lanka and all Southeast Asian nations are categorized as Asian (Gans, 2012; Glazer, 2001; Kaba, 2008, pp. 73-75, 2010, 2011a, p. 3, 2011b; Morning, 2000, 2005; Yancey, 2003). It is useful to note that these classifications are for this study only and do not claim that this is how these contributors and professors self identify.

For the institution or organization of employment and job titles/positions of all of the contributors, I continued to update many of them until early November 2012. The reason is that these contributors tend to move from one institution or organization to another and also move up in rank through promotions during the academic year. I combined contributors who do not directly work for academic departments and post-doctoral fellows under the category of Researcher/Post Doctoral Fellow. But for this current study, there is no Post Doctoral Fellow. There is also no Lecturer in this current study.

For the department or organization of employment, I combined all of the different types of names of the entities where they teach. For example, they include: Department, College, Faculty, Group, Division, School, Center, Unit, etc (also see Price, 2009, p. 333, who utilized "Department/Unit" in a study of economists). So the emphasis here is the entity in which they teach, not what they are teaching. After considerable thought, I also included the department of enrollment of the 2 graduate students ( 1 male and 1 female) in this section. The primary reason is that I could not be certain that these 2 graduate students do not do part-time work for those departments, including working on research projects for the entire department or for specific professors or serving as teaching assistants with a salary. It is very common for graduate students, especially Ph.D. students to do research work for pay with their professors because this is one important way for those professors to learn first-hand about their temperament, behavior, level of discipline or seriousness, skill level, and ability to work with others or in a group. In addition, these students are usually enrolled full-time, which means that enrollment in those departments become their full-time employment. The employment data focus on primary positions held.

The region of employment data is for the four geographic regions of the United States (Midwest, Northeast, South, and West; see Appendix A) and the United Nations classifications of countries and regions of the world (see Appendix B). For the U.S. states, Washington, D.C. is counted as a state equivalent.

For the earned degrees section, I only utilized the highest degree or terminal degree of the contributors. For example, there are graduate students who published full-length articles in the APSR in 2010, but still officially have only a bachelor's degree, or contributors who are not graduate students, but have a bachelor's degree or a masters' degree. That is why the phrase "Highest or Terminal Degrees" is utilized. For this study, each of the 79 contributors has one highest or terminal degree.

The institutions where these degrees are earned are also compiled and computed. The states and regions in the United States and countries and regions in the world of these institutions are also compiled and computed. Finally, I also compiled and computed the year that each degree is earned. The years ranged from 1968 to 2011.

To obtain the data for all of the variables, I conducted extensive research including the Curricular Vitae (CVs) of the contributors on their institutions'/organizations' websites, personal websites, newspaper and magazine articles about them, their Wikipedia pages, dissertations, etc. It is possible that not all of the data compiled on these contributors may be accurate. However, I spent thousands of hours as the only or sole scholar or researcher to carefully compile and compute these data for all three journals and I checked and rechecked them several times for the best possible accuracy. Some studies on rankings of economics and political science departments or economics journals in the past several years, for example, have also utilized the internet to compile data. For example, Breuning and Sanders (2007) used a similar method in a study of women who published articles in eight prestigious political science journals: "In the few cases where academic rank, academic discipline, or gender could not be determined on the basis of the biographical note, we relied on Internet searches" (p. 348). In a study ranking economics departments in the world, Amir and Knauff (2008) note that their, "data were collected in April 2006 directly from the Web sites of the relevant departments" (p. 185).

\section{General Statistical Findings and Analysis}

\subsection{Gender/Sex, Race and Title/Rank of Contributors to the American Political Science Review, 2010}

Within the political science profession in the United States, women and minorities continue to be underrepresented, from membership in the American Political Science Association; as faculty in lower ranks in political science departments; among contributors of full length articles to the American Political Science Review and other top political science journals; and among editorial board members in APSR and other 'top' political 
science journals (Alex-Assensoh et al., 2005; Ards et al., 1997; Brandes et al., 2001; Breuning \& Sanders, 2007; Cassese et al., 2012; Evans \& Moulder, 2011; Fisher et al., 1998; Grofman, 2009; Hesli \& Lee, 2011; Hesli et al., 2012; Lopez, 2003; Losco, 1998; Mann, 1998; Marshall \& Rothgeb, Jr., 2011; Miller \& Tien, 1996; Nelson \& Brammer, 2010; Rothgeb, Jr. \& Burger, 2009; Sampaio, 2006; Stegmaier et al., 2011; Young, 1995).

Women continue to earn less than half of bachelor's, master's and doctoral degrees in political science, but their rates have increased substantially over the past several decades. Young (1995) points out that: "More women populate political science classrooms and political science departments in colleges and universities across the country today than they did 10 years ago..." (p. 525). By 1995, women earned $40 \%$ of bachelor's degrees in political science (Young, 1995, p. 525). During the 2008-2009 academic year, women earned 45\% of bachelor's degrees in political science and government awarded by degree-granting institutions (Hesli et al., 2012, p. 476). Pertaining to bachelor's degree rates of Underrepresented Minorities (UMRs) and Asians, in 2005, URMs accounted for $20.8 \%$ bachelor's degrees in political science (Nelson \& Brammer, 2010, p. 5). In 2005, Blacks accounted for $10.3 \%$ of bachelor's degrees in political science; for Hispanics, $9.7 \%$ of bachelor's degrees in political science degrees; for Native Americans, $0.7 \%$ of bachelor's degrees in political science degrees; and for Asians, 7\% of political science degrees (Nelson \& Brammer, 2010, pp. 6 \& 12).

For master's and doctoral degrees, Young (1995) points out that women earned “...31\% of master's degrees, and $27 \%$ of doctoral degrees issued from American political science departments.... While women now receive 1 out of every 4 political science doctoral degrees, 20 years ago they received only 1 in 10" (p. 529). Hesli et al. (2012) note that women earned $23 \%$ of doctoral degrees from political science departments from 1981-1985, and then increased to $39 \%$ from 2001 to 2005 . By 2009, that figure increased to 40 percent (p. 476; also see Brandes et al., 2001, p. 320; Nelson \& Brammer, 2010, pp. 5-6 \& 12).

Nelson and Brammer (2010) note that in 2005 URM accounted for 13.9\% of Ph.D. recipients in political science (p. 5). For Blacks, from 1996 to 2005, they accounted for 8\% of Ph.D. recipients in political science: for Hispanics, $4 \%$ of Ph.D. recipients in political science; for Native Americans, $0.7 \%$ of Ph.D. recipients in political science; and for Asians, 5.2\% of Ph.D. recipients in political science (Nelson \& Brammer, 2010, pp. 6 \& 12). In 2011, of the 489 doctorates awarded in Political Science and Government to citizens and permanent residents in the United States, Whites accounted for 374 (76.5\%); Asians, 36 (7.4\%); Blacks, 28 (5.7\%); Hispanics, 24 (4.9\%); those who are two or more races, $10(2 \%)$; other or unknown race, $13(2.7 \%)$; and American Indian and Alaskan Native, 4 (0.8\%).(Note 1) (also see Ards \& Woodard, 1997, pp. 159-160; Brandes et al., 2001, p. 320).

The data on women employed as faculty members and their ranks within the political science discipline also show that they continue to be underrepresented, but have increased their rates in the past few decades. In the $1960 \mathrm{~s}$, women accounted for $5.5 \%$ of political science faculty members and by the $1980 \mathrm{~s}$, that figure increased to $15 \%$ (Young, 1995 , p. 525). By the $1999-2000$ academic year, women accounted for $22.2 \%$ of political science faculty (full-time) in the United States (Brandes et al., 2001, p. 320). Brandes et al. (2001) note that: "By academic rank, the most progress was made at the assistant professor level-which rose from $29.6 \%$ to $35 \%$ --compared to the growth made at full professor and associate professor levels-which rose from $9.4 \%$ to $11.2 \%$ and from 18.2\% to 22.8\% respectively-- from 1991 to 1998 " (p. 320; also see Young, 1995, p. 525). Looking at the faculty employment and rank rates, Stegmaier et al. (2011) point out that "... in 2010, $40 \%$ of assistant professors, $30 \%$ of associate professors, and 19\% of full professors were women" (p. 799; also see Hesli et al., p. 2012, p. 476; Nelson \& Brammer, 2010, pp. 14-18).

Nelson and Brammer (2010) point out that in Fiscal Year 2007, URM faculty accounted for $6.9 \%$ in political science (p. 5). For Blacks, they accounted for $4.2 \%$ of faculty in Top 100 political science departments; for Hispanics, 2.9\%; for Native Americans, 0.2\%; and for Asians, 5.6\% (Nelson \& Brammer, 2010, pp. 6 \& 12; also see Ards et at., 1997, pp. 160-161; Brandes et al., 2001, p. 320).

Looking at membership in the American Political Science Association (APSA), Stegmaier et al. (2011) point out that: "The overall representation of women in the field of political science has gradually, but slowly, increased...from $19 \%$ in 1991 to $29 \%$ by 2010 , with most gains being achieved at the junior levels" (p. 799 ; also see Ards et al., 1997, pp. 160-161; Losco, 1998, p. 839; Young, 1995, p. 525). According to Breuning and Sanders (2007): "Women's membership in the various sections of APSA varies between a low of $19.9 \%$ for political methodology to a high of $92.3 \%$ for women and politics. On average, women account for $32.2 \%$ of APSA membership (averaged across the section memberships). ...” (p. 348; also see Brandes et al., 2001, pp. 320-322).

Turning now to article publications by women in political science journals, including the APSR, according to Hesli et al. (2012):"Women have a lower average number of article publications at every rank" (pp.479). The 
research by Breuning and Sanders (2007) of the gender composition of contributors to eight top political science journals finds that, "Women make up an average of $20.9 \%$ of the authors if only the first author is considered, and 20.4\% if all authors are considered" (pp. 348-349). According to Young (1995): "Between 1983 and 1994, nearly 6,000 articles were published in the sample frame. Almost $24 \%$ of the articles have at least one female author. ...the lowest proportion of articles with female authors was 3.8 percent in the 1988 volume of APSR..." (Quoted from "How Much and Where Do Women Publish?" Section of non-pdf article; also see Brandes et al., 2001, pp. 320-322). The study of Evans and Moulder (2011) of the proportion of women contributors to selected number of political science journals (American Political Science Review, American Journal of Political Science, Journal of Politics, and PS: Political Science \& Politics) shows that from 2000 to 2009: "Overall, 553 research articles in our sample $(29.8 \%$ ) had at least one female author. Only $20 \%$ of the articles appearing in these journals had female lead authors.... the APSR had the lowest percentage (26.4\%) [of at least 1 female author]" (pp. 794-795). The research by Miller and Tien (1996) examines contributors of full-length articles to the American Political Science Review from 1954 to 1994 and point out that: "Over the last 40 years, 1,612 authors have published 1,980 articles (articles, research notes, controversies, and major subfield review essays) in APSR... An overwhelming majority of the authors have been male, but less so in the most recent 20 years. Between 1954 and 1973 just over $2 \%$ of the authors were female, and for the most recent 20 years (1974-94) $11 \%$ were female" (Quoted in "A Description of the Basic Data" Section of article).

Stegmaier et al. (2011) examine the gender make-up of editors in the top 50 political science journals in 2010 and find that: "95 people are titled editor among the 50 journals.... overall, 78 men and 17 women serve as editors, which translates into women holding $18 \%$ of the editorships. Because no journal employs more than one woman as editor, women work as editors at only one-third of these journals (17 of 50)" (p. 800).

\subsection{Gender/Sex of Contributors to the American Political Science Review, 2010}

For this current study, according to Table 1, of the 79 different contributors of full-length articles to all 4 regular issues of the APSR in 2010, women accounted for $11(13.9 \%)$.

Table 1. Gender/sex of contributors to the American Political Science Review, 2010 (all four regular issues) $\mathrm{N}=79$

\begin{tabular}{lrc}
\hline Gender/Sex & Number & \multicolumn{1}{c}{} \\
\hline Male & 68 & 86.1 \\
Female & 11 & 13.9 \\
Both Sexes & $\mathbf{7 9}$ & $\mathbf{1 0 0}$ \\
\hline
\end{tabular}

Source: Compiled and computed by author based on data provided by the American Political Science Review, 2010. Volume 104, Issues 1 to 4. http://journals.cambridge.org/action/displayBackIssues?jid=PSR; Articles also accessed on ProQuest Academic Search Engine.

\subsection{Racial/Cultural Background of Contributors to the American Political Science Review, 2010}

Table 2. Racial/cultural background of contributors to the American Political Science Review, 2010 (all four regular issues) $\quad \mathrm{N}=79$

\begin{tabular}{|c|c|c|c|c|c|c|c|c|}
\hline Race & Male & $\%$ & $\begin{array}{l}\% \text { of } \\
\text { Total }\end{array}$ & Female & $\%$ & $\begin{array}{l}\% \text { of } \\
\text { Total }\end{array}$ & Total & $\%$ \\
\hline White & 65 & 95.6 & 82.3 & 9 & 81.8 & 11.4 & 74 & 93.7 \\
\hline Eastern Asian & 2 & 2.9 & 2.5 & 0 & 0 & 0 & 2 & 2.5 \\
\hline Mestizo & 1 & 1.5 & 1.3 & 0 & 0 & 0 & 1 & 1.3 \\
\hline Black & 0 & 0 & 0 & 2 & 18.2 & 2.5 & 2 & 2.5 \\
\hline Total & 68 & 100 & 86.1 & 11 & 100 & 13.9 & 79 & 100 \\
\hline
\end{tabular}

Source: Compiled and computed by author based on data provided by the American Political Science Review, 2010. Volume 104, Issues 1 to 4. http://journals.cambridge.org/action/displayBackIssues?jid=PSR; Articles also accessed on ProQuest Academic Search Engine. 
According to Table 2, of the 79 contributors of full-length articles to the APSR in 2010, Whites accounted for 74 (93.7\%); 2 (2.5\%) Eastern Asians and Blacks each; and 1 (1.3\%) Mestizo. Of the 68 (86.1\% of total) males, Whites accounted for 65 (95.6\% of males, and $82.3 \%$ of total); 2 (2.9\% of males, and $2.5 \%$ of total) Eastern Asians; and 1 (1.5\% of males, and $1.3 \%$ of total) Mestizo. Of the $11(13.9 \%$ of total) females, Whites accounted for $9(81.9 \%$ of females, and $11.4 \%$ of total); and 2 (18.2\% of females, and $2.5 \%$ of total) Blacks (Table 2$)$.

\subsection{Job Titles/Positions of Contributors to the American Political Science Review, 2010}

Table 3 shows that the 79 different contributors of full-length articles to the APSR in 2010 held 80 positions (1 scholar holds 1 full professorship each in the U.S. and in Europe). Of the 80 positions held by all 79 contributors, 28 (35\%) are Full Professors; 25 (31.3\%) are Assistant Professors; 23 (28.8\%) are Associate Professors; 2 $(2.5 \%)$ are Graduate Students; and $1(1.3 \%)$ each is a Researcher and a Tutor. Of the 68 males with $69(86.4 \%$ of total) positions, 28 (40.6\% of male positions, and 35\% of total) are Full Professors; 20 (29\% of male positions, and $25 \%$ of total) are Assistant Professor; 18 (26.1\% of male positions, and $22.5 \%$ of total) are Associate Professors; and 1 (1.45\% of male positions, and $1.3 \%$ of total) each is a Tutor, Researcher, and a Graduate Student. Of the 11 females (13.9\% of total), 5 (45.45\% of females, and $6.3 \%$ of total) each are Associate Professors and Assistant Professors; and 1 (9\% of females, and 1.3\% of total) is a Graduate Student (Table 3).

Table 3. Job titles/positions of contributors to the American Political Science Review, 2010 (all four regular issues) $\quad \mathrm{N}=79$ contributors with 80 positions

\begin{tabular}{|c|c|c|c|c|c|c|c|c|}
\hline Job Title/Position & Male & $\%$ & $\begin{array}{l}\text { \% of } \\
\text { Total }\end{array}$ & Female & $\%$ & $\begin{array}{l}\text { \% of } \\
\text { Total }\end{array}$ & Total & $\%$ \\
\hline Full Professor & 28 & 40.6 & 35 & 0 & 0 & 0 & 28 & 35 \\
\hline Associate Professor & 18 & 26.1 & 22.5 & 5 & 45.45 & 6.3 & 23 & 28.8 \\
\hline Assistant Professor & 20 & 29 & 25 & 5 & 45.45 & 6.3 & 25 & 31.3 \\
\hline Tutor & 1 & 1.45 & 1.3 & 0 & 0 & 0 & 1 & 1.3 \\
\hline Researcher & 1 & 1.45 & 1.3 & 0 & 0 & 0 & 1 & 1.3 \\
\hline Graduate Student & 1 & 1.45 & 1.3 & 1 & 9 & 1.3 & 2 & 2.5 \\
\hline Total & 69 & 100.1 & 86.4 & 11 & 99.9 & 13.9 & 80 & 100.2 \\
\hline
\end{tabular}

Source: Compiled and computed by author based on data provided by the American Political Science Review, 2010. Volume 104, Issues 1 to 4. http://journals.cambridge.org/action/displayBackIssues?jid=PSR; Articles also accessed on ProQuest Academic Search Engine.

\subsection{Institution and Department of Employment of Contributors to the American Political Science Review, 2010}

There is a substantial body of research connecting contributors to the American Political Science Review and other influential political science journals to a selected group of departments at U.S. universities and some universities or institutions in Europe, especially the United Kingdom. Many of these studies rank political science departments and their universities. The variables used in these ranking studies of political science departments include total number of scholarly articles published including those in top ranked journals, size of the faculty, number of students enrolled or number of students who graduate each year, the networks these scholars belong to, amount of resources of the departments or the universities in which they are located, reputation of department and its university, etc. (Ballard \& Mitchell, 1998; Boncourt, 2007, pp. 283-284; Erne, 2007; Garand \& Graddy, 1999; Hesli et al., 2012; Hesli \& Lee, 2011; Hix, 2004; Ishiyama et al., 2010; Kaba, 2012a, pp. 28-29; Katz \& Eagles, 1996; Lowry \& Silver, 1996; Lopez, 2003; Mann, 1998; Masuoka et al., 2007ab; McCormick \& Rice, 2001; "Political Science Ranked in 2009," 2013; Schmidt \& Chingos, 2007).

In a study of the most highly cited 400 published political scientists from the 1950s to the 1980s, Masuoka et al. (2007a) point out that:

“...we see that the departments at Harvard, Yale, Chicago, Michigan, Berkeley, Princeton, and Columbia continue to be among the top producers overall of the most highly cited political scientists, and that those at Stanford and the University of North Carolina, Chapel Hill have moved up in ranking. Comparing across the seven decades sees more evidence of change. Generally the 
departments at the top 10 schools maintain their high status over the seven periods, but we do see a dip for Columbia's. Current gains by the departments at Cal Tech, MIT, Rochester, Washington University-St Louis, UC San Diego, and Duke are also worth noting since, especially in the last several decades, each has produced a number of scholars who make it to the top of the profession, and thus each would rise drastically in rankings based on production of recent Ph.D.s who have gone on to distinction" (p. 533).

The study of Katz and Eagles (1996) of the top ranked political science departments includes the following institutions: University of California-Berkeley, University of Michigan-Ann Arbor, Princeton University, University of California-Los Angeles, University of Clifornia-San Diego, the University of Wisconsin-Madison, the University of Rochester, Washington University, the University of Chicago, Yale University, Stanford University, Harvard University, Massachusetts Institute of Technology, Rice University, and the University of Iowa (Quoted in "Playing a Game With Nature: Adjusting Ratings to Account for Size and Rank of Political Science Departments" Section of article).

Lowry and Silver (1996) note that: “...the number of faculty members in a political science department and their average citations are important variables for predicting the department's reputation. However, departments gain their faculty and (in political science, at least) most of the resources to support the faculty's research from their university. Universities that value research are likely to provide such resources to many departments, not just a few" (p. 161).

According to the U.S. News \& World Report, the top 26 ranked political science departments in the United States in 2009 are: (\#1) Harvard University, Princeton University, and Stanford University; (\#4) University of Michigan-Ann Arbor; (\#5) Yale University; (\#6) University of California-Berkeley; (\#7) Columbia University and the University of California-San Diego; (\#9) Duke University and the Massachusetts Institute of Technology; (\#11) University of California-Los Angeles and the University of Chicago; (\#13) University of North Carolina - Chapel Hill and Washington University in St. Louis; (\#15) University of Rochester and the University of Wisconsin-Madison; (\#17) New York University, Ohio State University, and the University of Minnesota-Twin Cities; (\#20) Cornell University; (\#21) Northwestern University, University of Illinois-Urbana-Champaign, University of Texas-Austin; (\#24) Texas A\&M University-College Station, University of California-Davis; (\#26) Indiana University-Bloomington, and the University of Washington. (Note 2)

\subsection{Institution of Employment of Contributors to the American Political Science Review, 2010}

Table 4 shows that 79 contributors to the APSR in 2010 hold 80 positions, and the following 17 institutions employed 2 or more: Yale University, 9 (11.3\% of all 79), Harvard University and the University of Illinois at Urbana - Champaign, 4 (5\%) each; Florida State University, Massachusetts Institute of Technology, University of California-San Diego, and the University of Chicago, 3 (3.8\%) each; and Dartmouth College, Duke University, Northwestern University, Rice University, University of California-Merced, University of Oxford, University of Rochester, University of Wisconsin-Madison, University of Virginia, and Indiana University-Bloomington, 2 (2.5\%) each.

Of the 68 males with $69(86.25 \%$ of total) positions, 7 (10.1\% of male positions, and $8.75 \%$ of total) are employed by Yale University; 3 (4.3\% of male positions, and 3.75\% of total) each by Harvard University, the University of Illinois-Champaign, MIT, University of California-San Diego, and the University of Chicago; 2 ( $2.9 \%$ of male positions, and $2.5 \%$ of total) each by 9 different institutions; and 1 (1.45\% of male positions, and $1.25 \%$ of total) each by 28 different institutions. Of the 11 females with 11 (13.8\% of total) positions, 2 (18.5\% of females, and $2.5 \%$ of total) were employed by Yale University; and 1 ( $9.1 \%$ of females, and $1.25 \%$ of total) each employed by 9 different institutions (Table 4 ).

Table 4. Institution/organization of employment of contributors to the American Political Science Review, 2010 (all four regular issues) $\mathrm{N}=48$ Institutions/Organizations and 80 positions ( 1 contributor has 2 positions)

\begin{tabular}{|c|c|c|c|c|c|c|c|c|}
\hline Institution & Male & $\%$ & $\begin{array}{l}\% \text { of } \\
\text { Total }\end{array}$ & Female & $\%$ & $\begin{array}{l}\% \text { of } \\
\text { Total }\end{array}$ & Total & $\%$ \\
\hline Yale University & 7 & 10.1 & 8.75 & 2 & 18.2 & 2.5 & 9 & 11.3 \\
\hline Harvard University & 3 & 4.3 & 3.75 & 1 & 9.1 & 1.25 & 4 & 5 \\
\hline University of Illinois at Urbana-Champaign & 3 & 4.3 & 3.75 & 1 & 9.1 & 1.25 & 4 & 5 \\
\hline
\end{tabular}




\begin{tabular}{|c|c|c|c|c|c|c|c|c|}
\hline Florida State University & 2 & 2.9 & 2.5 & 1 & 9.1 & 1.25 & 3 & 3.8 \\
\hline Massachusetts Institute of Technology & 3 & 4.3 & 3.75 & 0 & 0 & 0 & 3 & 3.8 \\
\hline University OF California-San Diego & 3 & 4.3 & 3.75 & 0 & 0 & 0 & 3 & 3.8 \\
\hline University of Chicago & 3 & 4.3 & 3.75 & 0 & 0 & & 3 & 3.8 \\
\hline Dartmouth College & 2 & 2.9 & 2.5 & 0 & 0 & 0 & 2 & 2.5 \\
\hline Duke University & 1 & 1.5 & 1.25 & 1 & 9.1 & 1.25 & 2 & 2.5 \\
\hline Northwestern University & 2 & 2.9 & 2.5 & 0 & 0 & 0 & 2 & 2.5 \\
\hline Rice University & 2 & 2.9 & 2.5 & 0 & 0 & 0 & 2 & 2.5 \\
\hline University of California-Merced & 2 & 2.9 & 2.5 & 0 & 0 & 0 & 2 & 2.5 \\
\hline University of Oxford & 2 & 2.9 & 2.5 & 0 & 0 & 0 & 2 & 2.5 \\
\hline University of Rochester & 2 & 2.9 & 2.5 & 0 & 0 & 0 & 2 & 2.5 \\
\hline University of Wisconsin-Madison & 2 & 2.9 & 2.5 & 0 & 0 & 0 & 2 & 2.5 \\
\hline University of Virginia & 2 & 2.9 & 2.5 & 0 & 0 & 0 & 2 & 2.5 \\
\hline Indiana University-Bloomington & 1 & 1.45 & 1.25 & 1 & 9.1 & 1.25 & 2 & 2.5 \\
\hline Arizona State University & 1 & 1.45 & 1.25 & 0 & 0 & 0 & 1 & 1.25 \\
\hline \multicolumn{9}{|l|}{ Brooklyn College, City University of New } \\
\hline York & 1 & 1.45 & 1.25 & 0 & 0 & 0 & 1 & 1.25 \\
\hline College of William \& Mary & 1 & 1.45 & 1.25 & 0 & 0 & & 1 & 1.25 \\
\hline Columbia University & 1 & 1.45 & 1.25 & 0 & 0 & 0 & 1 & 1.25 \\
\hline Georgetown University & 1 & 1.45 & 1.25 & 0 & 0 & & 1 & 1.25 \\
\hline Loyola University-Chicago & 1 & 1.45 & 1.25 & 0 & 0 & 0 & 1 & 1.25 \\
\hline New York University & 1 & 1.45 & 1.25 & 0 & 0 & 0 & 1 & 1.25 \\
\hline Ohio State University & 1 & 1.45 & 1.25 & 0 & 0 & & 1 & 1.25 \\
\hline Oregon State University & 1 & 1.45 & 1.25 & 0 & 0 & 0 & 1 & 1.25 \\
\hline Princeton University & 0 & 0 & 0 & 1 & 9.1 & 1.25 & 1 & 1.25 \\
\hline Saint John's College-Annapolis, Maryland & 1 & 1.45 & 1.25 & 0 & 0 & 0 & 1 & 1.25 \\
\hline SMS Research \& Marketing Services & 1 & 1.45 & 1.25 & 0 & 0 & 0 & 1 & 1.25 \\
\hline Stockholm School of Economics & 1 & 1.45 & 1.25 & 0 & 0 & 0 & 1 & 1.25 \\
\hline Stockholm University & 1 & 1.45 & 1.25 & 0 & 0 & 0 & 1 & 1.25 \\
\hline University of Akron & 1 & 1.45 & 1.25 & 0 & 0 & 0 & 1 & 1.25 \\
\hline University of British Columbia & 1 & 1.45 & 1.25 & 0 & 0 & 0 & 1 & 1.25 \\
\hline University of California-Los Angeles & 1 & 1.45 & 1.25 & 0 & 0 & 0 & 1 & 1.25 \\
\hline University of California-Riverside & 1 & 1.45 & 1.25 & 0 & 0 & & 1 & 1.25 \\
\hline University of Colorado-Boulder & 1 & 1.45 & 1.25 & 0 & 0 & 0 & 1 & 1.25 \\
\hline University of Florida & 0 & 0 & 0 & 1 & 9.1 & 1.25 & 1 & 1.25 \\
\hline University of Houston & 1 & 1.45 & 1.25 & 0 & 0 & 0 & 1 & 1.25 \\
\hline University of Mary Washington & 0 & 0 & 0 & 1 & 9.1 & 1.25 & 1 & 1.25 \\
\hline University of Mississippi-Oxford & 1 & 1.45 & 1.25 & 0 & 0 & 0 & 1 & 1.25 \\
\hline University of North Carolina-Chapel Hill & 1 & 1.45 & 1.25 & 0 & 0 & 0 & 1 & 1.25 \\
\hline University of Notre Dame & 1 & 1.45 & 1.25 & 0 & 0 & 0 & 1 & 1.25 \\
\hline University of Tampa & 0 & 0 & 0 & 1 & 9.1 & 1.25 & 1 & 1.25 \\
\hline University of Wisconsin-Eau Claire & 1 & 1.45 & 1.25 & 0 & 0 & 0 & 1 & 1.25 \\
\hline University of Wisconsin-Milwaukee & 1 & 1.45 & 1.25 & 0 & 0 & 0 & 1 & 1.25 \\
\hline
\end{tabular}




\begin{tabular}{lrrrrrrrr}
\hline Vanderbilt University & 1 & 1.45 & 1.25 & 0 & 0 & 0 & 1 & 1.25 \\
Washington University in St. Louis & 1 & 1.45 & 1.25 & 0 & 0 & 0 & 1 & 1.25 \\
West Virginia University & 1 & 1.45 & 1.25 & 0 & 0 & 0 & 1 & 1.25 \\
Total & $\mathbf{6 9}$ & $\mathbf{9 9 . 8}$ & $\mathbf{8 6 . 2 5}$ & $\mathbf{1 1}$ & $\mathbf{1 0 0 . 1}$ & $\mathbf{1 3 . 8}$ & $\mathbf{8 0}$ & $\mathbf{1 0 0}$ \\
\hline
\end{tabular}

Source: Compiled and computed by author based on data provided by the American Political Science Review, 2010. Volume 104, Issues 1 to 4. http://journals.cambridge.org/action/displayBackIssues?jid=PSR; Articles also accessed on ProQuest Academic Search Engine.

\subsection{Department/Unit Etc. of Employment of Contributors to the American Political Science Review, 2010}

Table 5 shows that 78 contributors of full-length articles to the APSR in 2010 hold 79 positions at 10 academic institutions and 1 contributor is a researcher at an organization called SMS Research \& Marketing Services, Inc. Of the 79 positions, 64 (81\%) are in Political Science/Government/Politics; 5 (6.3\%) in Economics; 3 (3.8\%) Public Policy; and 1 (1.3\%) each in 7 different departments/units, etc. Of the 67 males with 68 (86.3\% of 79 total) positions, $56(82.4 \%$ of male positions, and $70.9 \%$ of total) are employed in a Department of Political Science/Government/Politics; 4 (5.9\% of male positions, and 5.1\% of total) in a Department of Economics; 3 ( $4.4 \%$ of male positions, and $3.8 \%$ of total) in a School of Public Policy; and 1 (1.5\% of male positions, and $1.3 \%$ of total) each employed in 5 different departments/units, etc. Of the 11 (14\% of total) females, 8 ( $72.7 \%$ of female positions, and $10.1 \%$ of total) are employed in a Department of Political Science/Government/Politics; and 1 (9.1\% of female positions, and $1.3 \%$ of total) each in the Department of Economics, Department of Government, History and World Affairs, and Department of Political Science \& International Relations (Table 5).

Table 5. Department/unit etc. of employment of contributors to the American Political Science Review, 2010 (all four regular issues) $\mathrm{N}=79$ contributors and 10 different departments, Faculties, Divisions, Schools, Units, etc. combined.

\begin{tabular}{|c|c|c|c|c|c|c|c|c|}
\hline Department, Faculty, Division, Sch., Unit, etc. & Male & $\%$ & $\begin{array}{l}\% \text { of } \\
\text { Total }\end{array}$ & Female & $\%$ & $\begin{array}{l}\% \text { of } \\
\text { Total }\end{array}$ & Total & $\%$ \\
\hline Political Science/Government/Politics & 56 & 82.4 & 70.9 & 8 & 72.7 & 10.1 & 64 & 81 \\
\hline Economics & 4 & 5.9 & 5.1 & 1 & 9.1 & 1.3 & 5 & 6.3 \\
\hline School of Public Policy & 3 & 4.4 & 3.8 & 0 & 0 & 0 & 3 & 3.8 \\
\hline Government, History and World Affairs & 0 & 0 & 0 & 1 & 9.1 & 1.3 & 1 & 1.3 \\
\hline Center for Government \& International Studies & 1 & 1.5 & 1.3 & 0 & 0 & 0 & 1 & 1.3 \\
\hline School of International Relations \& Pacific Studies & 1 & 1.5 & 1.3 & 0 & 0 & 0 & 1 & 1.3 \\
\hline Institute for International Economic Studies & 1 & 1.5 & 1.3 & 0 & 0 & 0 & 1 & 1.3 \\
\hline Politics \& International Relations & 1 & 1.5 & 1.3 & 0 & 0 & 0 & 1 & 1.3 \\
\hline Political Economy & 1 & 1.5 & 1.3 & 0 & 0 & 0 & 1 & 1.3 \\
\hline Political Science \& International Relations & 0 & 0 & 0 & 1 & 9.1 & 1.3 & 1 & 1.3 \\
\hline Total & 68 & 100.2 & 86.3 & 11 & 100 & 14 & 79 & 100.2 \\
\hline No Data & 1 & 1.5 & 1.26 & $\mathbf{0}$ & $\mathbf{0}$ & $\mathbf{0}$ & 1 & 1.27 \\
\hline
\end{tabular}

Source: Compiled and computed by author based on data provided by the American Political Science Review, 2010. Volume 104, Issues 1 to 4. http://journals.cambridge.org/action/displayBackIssues?jid=PSR; Articles also accessed on ProQuest Academic Search Engine.

3.8 U.S. States and Regions/World Regions and Countries of Employment of Contributors to the American Political Science Review, 2010

Whether within the United States (Midwest, Northeast, South and West), the Americas or the New World (North, Central and South, and the Caribbean), the Old World (Africa, Asia and Europe) or the planet Earth, 
there are always state (in the U.S.), country, regional and continental differences in educational attainment, household incomes, economic performance, etc. This is the same with publishing articles in scholarly journals, including the American Political Science Review (Boncourt, 2007; Garand \& Graddy, 1999, p. 114; Hix, 2004; Kaba, 2011, 2012; Masuok et al., 2007b, p. 361; Oprisko, 2012).

According to Table 6, all 79 different contributors hold 80 positions (one contributor holds a position each in the United States and the United Kingdom). Of the 80 positions, 76 (95.4\%) are held in Northern America: 75 $(94.15 \%)$ in the United States and $1(1.25 \%)$ in Canada. There are $4(5 \%)$ positions held in Northern Europe: 2 (2.5\%) each in Sweden and the United Kingdom. Of the 75 positions held in the United States, 24 (30.15\% of 80 total) are in the Northeast; 20 (25\%) each are in the Midwest and South; and $11(13.8 \%)$ are in the West. The following states have 3 positions or more: 10 (12.5\% of 80 total) in Illinois; $9(11.3 \%)$ in Connecticut; 7 (8.8\%) each in California and Massachusetts; 5 (6.3\%) each in Florida and New York; $4(5 \%)$ each in Wisconsin and Virginia; and 3 (3.8\%) each in Indiana, North Carolina and Texas.

For males, 65 (94.2\% of male positions, and 81.35\% of total) positions are held in Northern America: 64 (92.7\% of male positions, and $80.1 \%$ of total) positions are held in the United States; and 1 (1.45\% of male positions, and $1.25 \%$ of total) position are held in Canada. Of the 64 positions held by males in the United States, 20 ( $28.9 \%$ of male positions, and $25.05 \%$ of total) are held in the Northeast; 18 (26.1\% of male positions, and $22.55 \%$ of total) positions are held in the Midwest; 15 (21.9\% of male positions, and $18.75 \%$ of total) positions are held in the South; and $11(15.9 \%$ of male positions, and $13.75 \%$ of total) positions are held in the West. There are $4(5.8 \%$ of male positions, and 5\% of total) positions held in Northern Europe: $2(2.9 \%$ of male positions, and $2.5 \%$ of total) each in Sweden and the United Kingdom. Of the 11 female positions, 5 (45.5\% of female positions, and $6.25 \%$ of total) are held in the South; 4 (36.4\% of female positions, and $5 \%$ of total) are held in the Northeast; and 2 (18.2\% of female positions, and $2.5 \%$ of total) are held in the Midwest.

For individual states and countries, the following employed 3 or more male contributors: 9 (13\% of male positions, and $11.3 \%$ of total) are held in Illinois; 7 (10.1\% of male positions, and $8.75 \%$ of total) each are held in California and Connecticut; 6 (8.7\% of male positions, and 7.5\% of total) are held in Massachusetts; 5 (7.2\% of male positions, and $6.3 \%$ of total) are held in New York; 4 (5.8\% of male positions, and $5 \%$ of total) are held in Wisconsin; and 3 (4.4\% of male positions, and $3.75 \%$ of total) each are held in Texas and Virginia. For the 11 female positions, 3 (27.3\% of female positions, and $3.75 \%$ of total) are held in Florida; 2 (18.2\% of female positions, and $2.5 \%$ of total) are held in Connecticut; and 1 (9.1\% of female positions, and $1.25 \%$ of total) each is held in 6 other states (Table 6).

Table 6. U.S. states/regions and world regional geographic distribution of employment positions of contributors to the American Political Science Review, 2010 (all four regular issues)

$\mathrm{N}=24$ U.S. States and 4 Countries including the U.S.; 79 contributors with 80 positions $(1$ contributor has 2 positions, 1 in the U.S. and 1 in Europe)

\begin{tabular}{lrrrrrrrr}
\hline & \multicolumn{9}{c}{$\begin{array}{c}\text { \% of } \\
\text { State/Country }\end{array}$} & Male & \multicolumn{1}{c}{ \% } & Total & Female & \% & Total & Total & \% \\
\hline Northern America (n=2) & $\mathbf{6 5}$ & $\mathbf{9 4 . 2}$ & $\mathbf{8 1 . 3 5}$ & $\mathbf{1 1}$ & $\mathbf{1 0 0}$ & $\mathbf{1 3 . 7 5}$ & $\mathbf{7 6}$ & $\mathbf{9 5 . 4}$ \\
Canada (n=1) & $\mathbf{1}$ & $\mathbf{1 . 4 5}$ & $\mathbf{1 . 2 5}$ & $\mathbf{0}$ & $\mathbf{0}$ & $\mathbf{0}$ & $\mathbf{1}$ & $\mathbf{1 . 2 5}$ \\
United States (n=24) & $\mathbf{6 4}$ & $\mathbf{9 2 . 7}$ & $\mathbf{8 0 . 1}$ & $\mathbf{1 1}$ & $\mathbf{1 0 0}$ & $\mathbf{1 3 . 7 5}$ & $\mathbf{7 5}$ & $\mathbf{9 4 . 1 5}$ \\
Northeast (n=5) & $\mathbf{2 0}$ & $\mathbf{2 8 . 9}$ & $\mathbf{2 5 . 0 5}$ & $\mathbf{4}$ & $\mathbf{3 6 . 4}$ & $\mathbf{5}$ & $\mathbf{2 4}$ & $\mathbf{3 0 . 1 5}$ \\
Connecticut & 7 & 10.1 & 8.75 & 2 & 18.2 & 2.5 & 9 & 11.3 \\
Massachusetts & 6 & 8.7 & 7.5 & 1 & 9.1 & 1.25 & 7 & 8.8 \\
New York & 5 & 7.2 & 6.3 & 0 & 0 & 0 & 5 & 6.3 \\
New Hampshire & 2 & 2.9 & 2.5 & 0 & 0 & 0 & 2 & 2.5 \\
New Jersey & 0 & 0 & 0 & 1 & 9.1 & 1.25 & 1 & 1.25 \\
& & & & & & & & \\
Midwest (n=5) & $\mathbf{1 8}$ & $\mathbf{2 6 . 1}$ & $\mathbf{2 2 . 5 5}$ & $\mathbf{2}$ & $\mathbf{1 8 . 2}$ & $\mathbf{2 . 5}$ & $\mathbf{2 0}$ & $\mathbf{2 5 . 0 5}$ \\
Illinois & 9 & 13 & 11.3 & 1 & 9.1 & 1.25 & 10 & 12.5 \\
\hline
\end{tabular}




\begin{tabular}{|c|c|c|c|c|c|c|c|c|c|}
\hline Wisconsin & 4 & 5.8 & 5 & & 0 & 0 & 0 & 4 & 5 \\
\hline Indiana & 2 & 2.9 & 2.5 & & 1 & 9.1 & 1.25 & 3 & 3.8 \\
\hline Ohio & 2 & 2.9 & 2.5 & & 0 & 0 & 0 & 2 & 2.5 \\
\hline Missouri & 1 & 1.45 & 1.25 & & 0 & 0 & 0 & 1 & 1.25 \\
\hline South $(n=9)$ & 15 & 21.9 & 18.75 & & 5 & 45.5 & 6.25 & 20 & 25.15 \\
\hline Florida & 2 & 2.9 & 2.5 & & 3 & 27.3 & 3.75 & 5 & 6.3 \\
\hline Virginia & 3 & 4.4 & 3.75 & & 1 & 9.1 & 1.25 & 4 & 5 \\
\hline North Carolina & 2 & 2.9 & 2.5 & & 1 & 9.1 & 1.25 & 3 & 3.8 \\
\hline Texas & 3 & 4.4 & 3.75 & & 0 & 0 & 0 & 3 & 3.8 \\
\hline Maryland & 1 & 1.45 & 1.25 & & 0 & 0 & 0 & 1 & 1.25 \\
\hline Mississippi & 1 & 1.45 & 1.25 & & 0 & 0 & 0 & 1 & 1.25 \\
\hline Tennessee & 1 & 1.45 & 1.25 & & 0 & 0 & 0 & 1 & 1.25 \\
\hline Washington, DC & 1 & 1.45 & 1.25 & & 0 & $\mathbf{0}$ & 0 & 1 & 1.25 \\
\hline West Virginia & 1 & 1.45 & 1.25 & & 0 & 0 & 0 & 1 & 1.25 \\
\hline West $(n=5)$ & 11 & 15.9 & 13.75 & & $\mathbf{0}$ & $\mathbf{0}$ & $\mathbf{0}$ & 11 & 13.8 \\
\hline California & 7 & 10.1 & 8.75 & & 0 & 0 & 0 & 7 & 8.8 \\
\hline Arizona & 1 & 1.45 & 1.25 & & 0 & 0 & 0 & 1 & 1.25 \\
\hline Colorado & 1 & 1.45 & 1.25 & & 0 & 0 & 0 & 1 & 1.25 \\
\hline Hawaii & 1 & 1.45 & 1.25 & & 0 & 0 & 0 & 1 & 1.25 \\
\hline Oregon & 1 & 1.45 & 1.25 & & 0 & 0 & 0 & 1 & 1.25 \\
\hline Northern Europe (2) & 4 & 5.8 & 5 & & $\mathbf{0}$ & $\mathbf{0}$ & $\mathbf{0}$ & 4 & 5 \\
\hline Sweden & 2 & 2.9 & 2.5 & & 0 & 0 & 0 & 2 & 2.5 \\
\hline United Kingdom & 2 & 2.9 & 2.5 & & 0 & 0 & 0 & 2 & 2.5 \\
\hline Total & 69 & 100 & 86.35 & 11 & & 100 & 13.75 & 80 & 100.4 \\
\hline Extra Position & 1 & & & $\mathbf{0}$ & & & & 1 & \\
\hline
\end{tabular}

Source: Compiled and computed by author based on data provided by the American Political Science Review, 2010. Volume 104, Issues 1 to 4. http://journals.cambridge.org/action/displayBackIssues?jid=PSR; Articles also accessed on ProQuest Academic Search Engine.

3.9 Numbers and Types of Highest/Terminal Degrees Earned, Academic Major, Year Degrees Earned, Institutions of Earned Degrees, and U.S. States and Regions, Countries/World Regions of Earned Degrees (Tables 7 to 11) of Contributors to the American Political Science Review, 2010

Tables 7 to 11 present data examining the numbers and types of highest or terminal degrees earned, academic major/field, year degree is earned, institutions of earned degrees, and U.S. states and regions, countries and world regions of earned degrees of contributors of full-length articles to the American Political Science Review in 2010. All of these variables have been examined in research studies of political science professors in the United States and elsewhere. A substantial number of these studies focus on the programs or institutions where these scholars earned their doctoral degrees. Others focus on the rankings of the departments, including their geographic locations. Some studies focus on the scholarly productivity of either the scholars or professors of the top political science programs or the productivity of their graduates. Some studies focus on the job placement of recent graduates of the top programs in the discipline (Ballard \& Mitchell, 1998; Boncourt, 2007; Butler et al., 
2008; Dolan et al., 1997; Erne, 2007, p. 307; Fowler et al., 2007; Garand \& Graddy, 1999; Hesli \& Lee, 2011; Hix, 2004; Ishiyama, 2010; Kaba, 2011c; Katz \& Eagles, 1996; Lopez, 2003; Mann, 1998; Masuoka et al., 2007ab; McCormick \& Rice, 2001; Oprisko, 2012; Schmidt \& Chingos, 2007; Sigelman, 2006). In a study entitled "Demographics and Publication Productivity of Ivy League Political Science Professors: Harvard, Princeton, University of Pennsylvania and Yale," Kaba (2011) finds that as of October 2005: "Of the 198 professors for whom data for university of graduation were available, $102(51.5 \%)$ are from institutions in the Northeast and 39 (20\%) are from the West..." (Note 3) According to Masuoka et al. (2007b): “... in the early decades of the discipline, political science Ph.D. production was largely confined to institutions located in the Northeast and Midwest. Today, Northeastern and Midwestern schools total less than half of all Ph.D.-producing programs in the U.S., producing just barely above half of all Ph.D.s" (p. 361).

Explaining his research about the institutions that dominate the political science discipline, Oprisko (2012) claims that:

"Our research confirms that there is a direct correlation between institutional prestige and candidate placement. If we consider the highest ranked programs, the three tied at \#1, we find that Harvard University has successfully placed 239 political scientists at 75 institutions-including twelve at Harvard. Princeton has successfully placed 108 political scientists at 62 institutions - including five at Princeton. Stanford has successfully placed 128 political scientists at 51 institutions-including three at Stanford. The highest ranked public university, The University of Michigan at Ann Arbor (ranked number four overall), has successfully placed 141 political scientists in 61 institutions - including seven at Michigan. These four schools contribute 616 political scientists; roughly twenty percent of the total tenure-track lines in the discipline at research-intensive programs. The median institutional ranking for the 116 institutions covered is eleven, which implies that eleven schools contribute 50 percent of the political science academics to research-intensive universities in the United States. Over 100 political science $\mathrm{PhD}$ programs are graduating students that will contest the remaining 50 percent of openings."(Note 4)

According to the study by McCormick and Rice (2001):

"Table 1 ranks the top 20 political science departments based upon the weighted graduate-training productivity scores and shows the number of articles produced by graduates of these departments in each of the five journals. What is immediately striking is that, collectively, Big Ten, Ivy League, and West Coast political science departments dominate these rankings and that these departments have generally been recognized as the most prestigious in the profession. Furthermore, these top 20 departments dominate the absolute number of articles published in the five journals. The top 10 departments in this ranking, for instance, account for $37 \%$ of the articles in these journals, while the top 20 departments account for 58\%" (pp. 676-677).

The top 20 political science departments in the study by McCormick and Rice (2001) are in the following institutions: Michigan, Berkeley, Chicago, Rochester, Indiana, Yale, Iowa, Minnesota, Wisconsin, Stanford, North Carolina, Harvard, Princeton, Washington, St. Louis, Ohio State, Duke, UCLA, Michigan State, Colorado, and Texas, (p. 676). Figure 1 of the study by Fowler et al. (2007): “... reveals the extent to which there is an apparent core-periphery structure, with a density of ties in the center of the graph around the political science departments at Harvard, Chicago, and Columbia, with further strong ties to departments such as Yale, Berkeley, and Michigan, and then to departments such as Stanford, Princeton, Wisconsin, Northwestern, UCLA, Cornell, and Indiana." (p. 731). Table A1 in Fowler's (2007) study is entitled: " Ph.D. Students Placed at Other U.S. Ph.D.-Granting Institutions (1960-2002) and Department Size (2002)" and the top 20 institutions are: Harvard (278 placements), Berkeley (208), Chicago (198), Yale (176), Columbia (174), Michigan (172), Princeton (143), Stanford (107), Wisconsin (101), Minnesota (92), UCLA (86), Indiana (82), M.I.T. (78), Northwestern (77), Cornell (75), North Carolina (73), Johns Hopkins (59), Ohio State (59), Syracuse (56), Washington University (47), Duke (46), Rochester (44), Iowa (42), Illinois-Urbana Champaign (38), Texas (36) (p. 738; Masuoka et al., 2007b, pp. 361-362).

A study by McCormick and Rice (2001) of five prestigious political science journals that published 1,057 "articles and research notes" from 1994 to 1998 claim that: "Authors from foreign institutions wrote only 4.7\% of the articles" (pp. 675-676). 
3.10 Numbers and Types of Highest/Terminal Degrees Earned by Contributors to the American Political Science Review, 2010

According to Table 7, all 79 contributors earned 5 different types of highest or terminal degrees, with each earning a degree. Of the 79 degrees, 74 (93.7\%) are Ph.D.s.; 2 (2.5\%) are M.A.s; and 1 (1.3\%) each is a B.A., D.Phill., and M.P.I.A. Of the 68 ( $86.1 \%$ of total) male contributors, 64 (94.1\% of males, and $81 \%$ of total) earned a Ph.D.; 2 (2.9\% of males, and $2.5 \%$ of total) earned an M.A.; and 1 (1.5\% of males, and $1.3 \%$ of total) each earned a D.Phil. and an M.P.I.A. Of the 11 (14\% of total) females, $10(90.9 \%$ of females, and $12.7 \%$ of total) earned a Ph.D.; and 1 (9.1\% of females, and $1.3 \%$ of total) earned a B.A. (Table 7).

Table 7. Numbers and types of highest/terminal degrees of contributors to the American Political Science Review, 2010 (all four regular issues)

$\mathrm{N}=79$ contributors and 5 different degree types

\begin{tabular}{|c|c|c|c|c|c|c|c|c|}
\hline Degree Type & Male & $\%$ & $\begin{array}{l}\% \text { of } \\
\text { Total }\end{array}$ & Female & $\%$ & $\begin{array}{l}\% \text { of } \\
\text { Total }\end{array}$ & Total & $\%$ \\
\hline Ph.D. & 64 & 94.1 & 81 & 10 & 90.9 & 12.7 & 74 & 93.7 \\
\hline D.Phil. & 1 & 1.5 & 1.3 & 0 & 0 & 0 & 1 & 1.3 \\
\hline M.P.I.A. & 1 & 1.5 & 1.3 & 0 & 0 & 0 & 1 & 1.3 \\
\hline M.A. & 2 & 2.9 & 2.5 & 0 & 0 & 0 & 2 & 2.5 \\
\hline B.A. & 0 & 0 & 0 & 1 & 9.1 & 1.3 & 1 & 1.3 \\
\hline Total & 68 & 100 & 86.1 & 11 & 100 & 14 & 79 & 100.1 \\
\hline
\end{tabular}

Source: Compiled and computed by author based on data provided by the American Political Science Review, 2010. Volume 104, Issues 1 to 4. http://journals.cambridge.org/action/displayBackIssues?jid=PSR; Articles also accessed on ProQuest Academic Search Engine.

\subsection{Academic Major/Field of Earned Highest or Terminal Degrees by Contributors to the American Political} Science Review, 2010

All 79 contributors earned their 79 degrees (1 each) in just 3 majors: 70 (88.6\%) in Political Science/Government; 8 (10.1\%) in Economics; and 1 (1.3\%) in Math. Of the 68 (86.1\% total) males, $60(88.2 \%$ of males, and $75.9 \%$ of total) earned their highest or terminal degrees in Political Science/Government; 7 (10.3\% of males, and $8.9 \%$ of total) earned their degrees in Economics; and 1 (1.5\% of males, and $1.3 \%$ of total) earned his degree in Math. Of the 11 (14\% of total) females, 10 (90.9\% of females, and $12.7 \%$ of total) earned their degrees in Political Science/Government; and 1(9.1\% of females, and $1.3 \%$ of total) earned her degree in Economics (Table 8).

Table 8. Academic major/field of earned highest or terminal degrees by contributors to the American Political Science Review, 2010 (all four issues)

$\mathrm{N}=79$ contributors and 3 academic majors/fields

\begin{tabular}{|c|c|c|c|c|c|c|c|c|}
\hline Major/Field & Male & $\%$ & $\begin{array}{l}\% \text { of } \\
\text { Total }\end{array}$ & Female & $\%$ & $\begin{array}{l}\text { \% of } \\
\text { Total } \\
\end{array}$ & Total & $\%$ \\
\hline Political Science/Government & 60 & 88.2 & 75.9 & 10 & 90.9 & 12.7 & 70 & 88.6 \\
\hline Economics & 7 & 10.3 & 8.9 & 1 & 9.1 & 1.3 & 8 & 10.1 \\
\hline Math & 1 & 1.5 & 1.3 & 0 & 0 & 0 & 1 & 1.3 \\
\hline Total & 68 & 100 & 86.1 & 11 & 100 & 14 & 79 & 100 \\
\hline
\end{tabular}

Source: Compiled and computed by author based on data provided by the American Political Science Review, 2010. Volume 104, Issues 1 to 4. http://journals.cambridge.org/action/displayBackIssues?jid=PSR; Articles also accessed on ProQuest Academic Search Engine. 
3.12 Institution of Graduation with Highest or Terminal Degrees of Contributors to the American Political Science Review, 2010

According to Table 9, of the 79 degrees (34 different institutions) earned by each of the 79 contributors to the APSR in 2010, 10 institutions conferred 3 degrees or more: 9 (11.4\%) from Harvard University; 7 (8.9\%) each from the University of Chicago and the University of Rochester; 5 (6.3\%) from the University of California-Berkeley; 4 (5.1\%) from Duke University; 3 (3.8\%) each from Columbia University, Indiana University, MIT, Ohio State University, and the University of Pittsburgh.

Of the $68(85.82 \%$ of total) males, 7 institutions conferred 3 or more highest or terminal degrees to them: 8 ( $11.8 \%$ of males, and $10.1 \%$ of total) from Harvard University; 7 (10.3\% of males, and $8.9 \%$ of total) each from the University of Chicago and the University of Rochester; 4 (5.9\% of males, and $5.1 \%$ of total) from the University of California-Berkeley; and 3 (4.4\% of males, and 3.8\% of total) each from Duke University, Indiana University, and Ohio State University. Eight institutions conferred 2 (2.9\% of males, and $2.5 \%$ of total) degrees each; and 1 (1.5\% of males, and $1.26 \%$ of total) degree each from 17 different institutions. Of the 11 females, Yale University conferred 2 (18.2\% of females, and $2.5 \%$ of total) degrees; and 1 (9.1\% of females, and $1.3 \%$ of total) degree each from 9 different institutions (Table 9).

Table 9. Institution of graduation with highest or terminal degrees of contributors to the American Political Science Review, 2010 (all four issues) N=34 institutions and 79 degrees

\begin{tabular}{|c|c|c|c|c|c|c|c|c|}
\hline Institution & Male & $\%$ & $\begin{array}{l}\% \text { of } \\
\text { Total }\end{array}$ & Female & $\%$ & $\begin{array}{l}\% \text { of } \\
\text { Total }\end{array}$ & Total & $\%$ \\
\hline Harvard University & 8 & 11.8 & 10.1 & 1 & 9.1 & 1.3 & 9 & 11.4 \\
\hline University of Chicago & 7 & 10.3 & 8.9 & 0 & 0 & 0 & 7 & 8.9 \\
\hline University of Rochester & 7 & 10.3 & 8.9 & 0 & 0 & 0 & 7 & 8.9 \\
\hline University of California-Berkeley & 4 & 5.9 & 5.1 & 1 & 9.1 & 1.3 & 5 & 6.3 \\
\hline Duke University & 3 & 4.4 & 3.8 & 1 & 9.1 & 1.3 & 4 & 5.1 \\
\hline Columbia University & 2 & 2.9 & 2.5 & 1 & 9.1 & 1.3 & 3 & 3.8 \\
\hline Indiana University & 3 & 4.4 & 3.8 & 0 & 0 & 0 & 3 & 3.8 \\
\hline Massachusetts Institute of Technology & 2 & 2.9 & 2.5 & 1 & 9.1 & 1.3 & 3 & 3.8 \\
\hline Ohio State University & 3 & 4.4 & 3.8 & 0 & 0 & 0 & 3 & 3.8 \\
\hline University of Pittsburgh & 2 & 2.9 & 2.5 & 1 & 9.1 & 1.3 & 3 & 3.8 \\
\hline Cornell University & 2 & 2.9 & 2.5 & 0 & 0 & 0 & 2 & 2.5 \\
\hline Stanford University & 2 & 2.9 & 2.5 & 0 & 0 & 0 & 2 & 2.5 \\
\hline Stockholm School of Economics & 2 & 2.9 & 2.5 & 0 & 0 & 0 & 2 & 2.5 \\
\hline University of Illinois & at & & & & & & & \\
\hline Urbana-Champaign & 1 & 1.5 & 1.26 & 1 & 9.1 & 1.3 & 2 & 2.5 \\
\hline University OF California-San Diego & 2 & 2.9 & 2.5 & 0 & 0 & 0 & 2 & 2.5 \\
\hline University of Oxford & 2 & 2.9 & 2.5 & 0 & 0 & 0 & 2 & 2.5 \\
\hline Vanderbilt University & 1 & 1.5 & 1.26 & 1 & 9.1 & 1.3 & 2 & 2.5 \\
\hline Yale University & 0 & 0 & 0 & 2 & 18.2 & 2.5 & 2 & 2.5 \\
\hline SUNY, Binghamton & 1 & 1.5 & 1.26 & 0 & 0 & 0 & 1 & 1.3 \\
\hline City University of New York & 1 & 1.5 & 1.26 & 0 & 0 & 0 & 1 & 1.3 \\
\hline Florida State University & 0 & 0 & 0 & 1 & 9.1 & 1.3 & 1 & 1.3 \\
\hline George Washington & 1 & 1.5 & 1.26 & 0 & 0 & 0 & 1 & 1.3 \\
\hline Loyola University-Chicago & 1 & 1.5 & 1.26 & 0 & 0 & 0 & 1 & 1.3 \\
\hline Northwestern University & 1 & 1.5 & 1.26 & 0 & 0 & 0 & 1 & 1.3 \\
\hline Princeton University & 1 & 1.5 & 1.26 & 0 & 0 & 0 & 1 & 1.3 \\
\hline
\end{tabular}




\begin{tabular}{lrrrrrrrr}
\hline University of California-Davis & 1 & 1.5 & 1.26 & 0 & 0 & 0 & 1 & 1.3 \\
University of California-Santa Barbara & 1 & 1.5 & 1.26 & 0 & 0 & 0 & 1 & 1.3 \\
University of Colorado-Boulder & 1 & 1.5 & 1.26 & 0 & 0 & 0 & 1 & 1.3 \\
University of Houston & 1 & 1.5 & 1.26 & 0 & 0 & 0 & 1 & 1.3 \\
University of Maryland-College Park & 1 & 1.5 & 1.26 & 0 & 0 & 0 & 1 & 1.3 \\
University of Michigan-Ann Arbor & 1 & 1.5 & 1.26 & 0 & 0 & 0 & 1 & 1.3 \\
University of Munich & 1 & 1.5 & 1.26 & 0 & 0 & 0 & 1 & 1.3 \\
University of Vienna & 1 & 1.5 & 1.26 & 0 & 0 & 0 & 1 & 1.3 \\
University of Washington-Seattle & 1 & 1.5 & 1.26 & 0 & 0 & 0 & 1 & 1.3 \\
Total & $\mathbf{6 8}$ & $\mathbf{1 0 0 . 2}$ & $\mathbf{8 5 . 8 2}$ & $\mathbf{1 1}$ & $\mathbf{1 0 0}$ & $\mathbf{1 4 . 2}$ & $\mathbf{7 9}$ & $\mathbf{1 0 0 . 4}$ \\
\hline
\end{tabular}

Source: Compiled and computed by author based on data provided by the American Political Science Review, 2010. Volume 104, Issues 1 to 4. http://journals.cambridge.org/action/displayBackIssues?jid=PSR; Articles also accessed on ProQuest Academic Search Engine.

\subsection{U.S. States and Regions/Countries and World Regions Where Earned Highest or Terminal Degree Institutions are Located of Contributors to the American Political Science Review, 2010}

Each of the 79 contributors to the APSR in 2010 earned 1 highest or terminal degree. Of the 79 degrees, 73 $(92.6 \%)$ are earned in 18 states in the United States and $6(7.6 \%)$ degrees earned in 4 countries in Europe; 4 (5\% of 79 total) in Northern Europe (2 (2.5\%) each in Sweden and the United Kingdom and $2(2.5 \%)$ in Western Europe (1 (1.3\%) each in Austria and Germany. Of the 73 degrees earned in the United States, 32 (40.5\% of 79) are in 5 states in the Northeast; $18(22.8 \%)$ in 4 states in the Midwest; $13(16.5 \%)$ in 3 states in the West; and 10 $(12.8 \%)$ in 6 states in the South. The following 4 states awarded degrees in double figures: $14(17.7 \%$ of 79$)$ in New York; 12 (15.2\%) in Massachusetts; and 11 (13.9\%) each in California and Illinois.

For the 68 males, 62 (91.3\% of males, and $78.5 \%$ of total) earned their degrees in the United States: 26 (38.2\% of males, and $32.9 \%$ of total) in 4 states in the Northeast; 17 (25\% of males, and $21.6 \%$ of total) from 4 states in the Midwest; 12 (17.7\% of males, and $15.22 \%$ of total) from 3 states in the West; and 7 (10.4\% of males, and $8.84 \%$ of total) from 5 states in the South. There are $6(8.8 \%$ of males, and $7.5 \%$ of total $)$ degrees earned in Europe: 4 (5.8\% of males, and 5\% of total) from 2 countries each in Northern Europe (2 $(2.9 \%$ of males, and $2.5 \%$ of total) each in Sweden and the United Kingdom; and 2 countries in Western Europe (1 (1.5\%) each in Austria and Germany). All 11 females earned their highest or terminal degrees in the United States: 6 (54.6\% of females, and $7.6 \%$ of total) in 4 states in the Northeast; 3 (27.3\% of females, and $3.9 \%$ of total) in 3 states in the South; and 1 (9.1\% of females, and $1.3 \%$ of total) each in the Midwest and West (Table 10).

Table 10. U.S. states and regions/countries and world regions where earned highest or terminal degree institutions are located of contributors to the American Political Science Review, 2010 (all four issues) N=79 contributors; 18 U.S. states and 5 countries, including the United States

\begin{tabular}{lrrrrrrrr}
\hline & \multicolumn{9}{c}{$\begin{array}{c}\text { \% of } \\
\text { State/Country }\end{array}$} & Male & \multicolumn{1}{c}{$\begin{array}{c}\text { Total } \\
\text { United States }\end{array}$} & $\mathbf{6 2}$ & $\mathbf{9 1 . 3}$ & $\mathbf{7 8 . 4 8}$ & $\mathbf{1 1}$ & $\mathbf{1 0 0}$ & $\mathbf{1 4 . 1}$ & $\mathbf{7 3}$ & $\mathbf{9 2 . 6}$ \\
Northeast (5) & $\mathbf{2 6}$ & $\mathbf{3 8 . 2}$ & $\mathbf{3 2 . 8 6}$ & $\mathbf{6}$ & $\mathbf{5 4 . 6}$ & $\mathbf{7 . 5 6}$ & $\mathbf{3 2}$ & $\mathbf{4 0 . 5}$ \\
New York & 13 & 19.1 & 16.4 & 1 & 9.1 & 1.26 & 14 & 17.7 \\
Massachusetts & 10 & 14.7 & 12.7 & 2 & 18.2 & 2.5 & 12 & 15.2 \\
Pennsylvania & 2 & 2.9 & 2.5 & 1 & 9.1 & 1.3 & 3 & 3.8 \\
Connecticut & 0 & 0 & 0 & 2 & 18.2 & 2.5 & 2 & 2.5 \\
New Jersey & 1 & 1.5 & 1.26 & 0 & 0 & 0 & 1 & 1.3 \\
& & & & & & & & \\
Midwest (4) & $\mathbf{1 7}$ & $\mathbf{2 5}$ & $\mathbf{2 1 . 5 6}$ & $\mathbf{1}$ & $\mathbf{9 . 1}$ & $\mathbf{1 . 3}$ & $\mathbf{1 8}$ & $\mathbf{2 2 . 8}$ \\
\hline
\end{tabular}




\begin{tabular}{|c|c|c|c|c|c|c|c|c|c|}
\hline Illinois & 10 & 14.7 & 12.7 & & 1 & 9.1 & 1.3 & 11 & 13.9 \\
\hline Indiana & 3 & 4.4 & 3.8 & & 0 & 0 & 0 & 3 & 3.8 \\
\hline Ohio & 3 & 4.4 & 3.8 & & 0 & 0 & 0 & 3 & 3.8 \\
\hline Michigan & 1 & 1.5 & 1.26 & & 0 & 0 & 0 & 1 & 1.3 \\
\hline South (6) & 7 & 10.4 & 8.84 & & 3 & 27.3 & 3.9 & 10 & 12.8 \\
\hline North Carolina & 3 & 4.4 & 3.8 & & 1 & 9.1 & 1.3 & 4 & 5.1 \\
\hline Tennessee & 1 & 1.5 & 1.26 & & 1 & 9.1 & 1.3 & 2 & 2.5 \\
\hline Florida & 0 & 0 & 0 & & 1 & 9.1 & 1.3 & 1 & 1.3 \\
\hline Maryland & 1 & 1.5 & 1.26 & & 0 & 0 & 0 & 1 & 1.3 \\
\hline Texas & 1 & 1.5 & 1.26 & & 0 & 0 & 0 & 1 & 1.3 \\
\hline Washington, D.C. & 1 & 1.5 & 1.26 & & 0 & 0 & 0 & 1 & 1.3 \\
\hline West (3) & 12 & 17.7 & 15.22 & & 1 & 9.1 & 1.3 & 13 & 16.5 \\
\hline California & 10 & 14.7 & 12.7 & & 1 & 9.1 & 1.3 & 11 & 13.9 \\
\hline Colorado & 1 & 1.5 & 1.26 & & 0 & 0 & 0 & 1 & 1.3 \\
\hline Washington & 1 & 1.5 & 1.26 & & 0 & 0 & 0 & 1 & 1.3 \\
\hline Europe (4) & 6 & 8.8 & 7.52 & & $\mathbf{0}$ & $\mathbf{0}$ & $\mathbf{0}$ & 6 & 7.6 \\
\hline Northern Europe (2) & 4 & 5.8 & 5 & & $\mathbf{0}$ & $\mathbf{0}$ & $\mathbf{0}$ & 4 & 5 \\
\hline Sweden & 2 & 2.9 & 2.5 & & 0 & 0 & 0 & 2 & 2.5 \\
\hline United Kingdom & 2 & 2.9 & 2.5 & & 0 & 0 & 0 & 2 & 2.5 \\
\hline Western Europe (2) & 2 & 3 & 2.52 & & $\mathbf{0}$ & $\mathbf{0}$ & $\mathbf{0}$ & 2 & 2.6 \\
\hline Austria & 1 & 1.5 & 1.26 & & 0 & 0 & 0 & 1 & 1.3 \\
\hline Germany & 1 & 1.5 & 1.26 & & 0 & 0 & 0 & 1 & 1.3 \\
\hline Total & 68 & 100 & 86 & 11 & & 100 & 14.9 & 79 & 100.2 \\
\hline
\end{tabular}

Source: Compiled and computed by author based on data provided by the American Political Science Review, 2010. Volume 104, Issues 1 to 4. http://journals.cambridge.org/action/displayBackIssues?jid=PSR; Articles also accessed on ProQuest Academic Search Engine.

3.14 Year of Highest or Terminal Degree Attainment (1968-2012) by Contributors to the American Political Science Review, 2010

Of the 79 highest or terminal degrees earned by contributors to the APSR in 2010 from 1968 to 2011, the following years have 3 or more: 7 (8.7\% of total) in 2002; 6 (7.6\%) each in 1995, 2007, and 2008; 4 (5.1\%) each in $1997,1999,2000$, and 2009; and $3(3.8 \%)$ each in 1998, 2002, 2003, and 2004. For the 68 males, $6(8.8 \%$ of males, and $7.6 \%$ of total) degrees each were earned in 1995 and $2008 ; 5$ (7.3\% of males, and $6.3 \%$ of total) degrees each were earned in 2002 and 2007; 4 (5.9\% of males, and 5.1\% of total) degrees were earned in 2000; 3 (4.4\% of males, and 3.8\% of total) degrees each were earned in 1997, 1998, 1999, 2004, and 2009; 2 (2.9\% of males, and $2.5 \%$ of total) degrees each earned in 9 different years; and 1 (1.5\% of males, and $1.3 \%$ of total) degree each earned in 9 different years. Of the 11 (14\% of total) females, 2 (18\% of females, and $2.5 \%$ of total) each earned degrees in 2002 and 2010; and 1 (9.1\% of females, and $1.3 \%$ of total) degree each earned by 7 females in 7 different years (Table 11). 
Table 11. Year of highest or terminal degree attainment of contributors to the American Political Science Review, 2010 (all four regular issues) (1968-2011)

$\mathrm{N}=29$ Different years and 79 contributors with 79 Degrees (each with 1 degree)

\begin{tabular}{|c|c|c|c|c|c|c|c|c|}
\hline Year & Male & $\%$ & $\begin{array}{l}\% \text { of } \\
\text { Total } \\
\end{array}$ & Female & $\%$ & $\begin{array}{l}\% \text { of } \\
\text { Total } \\
\end{array}$ & Total & $\%$ \\
\hline 1968 & 1 & 1.5 & 1.3 & 0 & 0 & 0 & 1 & 1.27 \\
\hline 1974 & 1 & 1.5 & 1.3 & 0 & 0 & 0 & 1 & 1.27 \\
\hline 1978 & 2 & 2.9 & 2.5 & 0 & 0 & 0 & 2 & 2.5 \\
\hline 1980 & 1 & 1.5 & 1.3 & 0 & 0 & 0 & 1 & 1.27 \\
\hline 1982 & 1 & 1.5 & 1.3 & 0 & 0 & 0 & 1 & 1.27 \\
\hline 1983 & 1 & 1.5 & 1.3 & 0 & 0 & 0 & 1 & 1.27 \\
\hline 1987 & 1 & 1.5 & 1.3 & 0 & 0 & 0 & 1 & 1.27 \\
\hline 1990 & 2 & 2.9 & 2.5 & 0 & 0 & 0 & 2 & 2.5 \\
\hline 1991 & 2 & 2.9 & 2.5 & 0 & 0 & 0 & 2 & 2.5 \\
\hline 1992 & 1 & 1.5 & 1.3 & 0 & 0 & 0 & 2 & 2.5 \\
\hline 1993 & 2 & 2.9 & 2.5 & 0 & 0 & 0 & 2 & 2.5 \\
\hline 1994 & 2 & 2.9 & 2.5 & 0 & 0 & 0 & 2 & 2.5 \\
\hline 1995 & 6 & 8.8 & 7.6 & 0 & 0 & 0 & 6 & 7.6 \\
\hline 1996 & 1 & 1.5 & 1.3 & 0 & 0 & 0 & 1 & 1.27 \\
\hline 1997 & 3 & 4.4 & 3.8 & 1 & 9.1 & 1.3 & 4 & 5.1 \\
\hline 1998 & 3 & 4.4 & 3.8 & 0 & 0 & 0 & 3 & 3.8 \\
\hline 1999 & 3 & 4.4 & 3.8 & 1 & 9.1 & 1.3 & 4 & 5.1 \\
\hline 2000 & 4 & 5.9 & 5.1 & 0 & 0 & 0 & 4 & 5.1 \\
\hline 2001 & 2 & 2.9 & 2.5 & 0 & 0 & 0 & 2 & 2.5 \\
\hline 2002 & 5 & 7.3 & 6.3 & 2 & 18 & 2.5 & 7 & 8.7 \\
\hline 2003 & 2 & 2.9 & 2.5 & 1 & 9.1 & 1.3 & 3 & 3.8 \\
\hline 2004 & 3 & 4.4 & 3.8 & 0 & & 0 & 3 & 3.8 \\
\hline 2005 & 2 & 2.9 & 2.5 & 1 & 9.1 & 1.3 & 3 & 3.8 \\
\hline 2006 & 2 & 2.9 & 2.5 & 0 & 0 & 0 & 2 & 2.5 \\
\hline 2007 & 5 & 7.3 & 6.3 & 1 & 9.1 & 1.3 & 6 & 7.6 \\
\hline 2008 & 6 & 8.8 & 7.6 & 1 & 9.1 & 1.3 & 6 & 7.6 \\
\hline 2009 & 3 & 4.4 & 3.8 & 1 & 9.1 & 1.3 & 4 & 5.1 \\
\hline 2010 & 0 & 0 & 0 & 2 & 18 & 2.5 & 2 & 2.5 \\
\hline 2011 & 1 & 1.5 & 1.3 & 0 & 0 & 0 & 1 & 1.27 \\
\hline Total & 68 & 99.7 & 86.1 & 11 & 100 & 14.1 & 79 & 99.8 \\
\hline
\end{tabular}

Source: Compiled and computed by author based on data provided by the American Political Science Review, 2010. Volume 104, Issues 1 to 4 . http://journals.cambridge.org/action/displayBackIssues?jid=PSR; Articles also accessed on ProQuest Academic Search Engine.

\section{Discussion and Conclusion}

The data in the tables above have provided many important findings pertaining to various characteristics of the contributors of full-length articles to the American Political Science Review in 2010, and the discipline as a whole. For example, the APSR is mostly dominated by contributors who earned their terminal degrees and are employed at the most influential academic institutions in the United States. These institutions and the scholars who work there are noted to have developed a culture of elitism and this is observed through the placement of 
their political science Ph.D. graduates, who tend to be employed either by their own or a network of relatively small group of elite institutions (Kaba, 2011c; Masuoka et al., 2007b; Oprisko, 2012). Masuoka et al. (2007b) discussed this culture of elitism among departments and their institutions within the political science discipline: "We conclude with a discussion of our findings as they relate to the degree of elitism in the production and placement of political science Ph.D.s in the later as compared to the earlier part of the twentieth century.... Thus, the culture of the discipline through the first half of the century was characterized by a striking degree of elitism; not all departments were considered equal" (p. 361). Explaining the placement of Ph.D. political science graduates at various institutions in the United States over several decades, Masuoka et al. (2007b) identified the top eight universities that are very influential: University of California-Berkeley, University of Chicago, Columbia University, Harvard University, University of Michigan, Princeton University, Stanford University, and Yale University. The "big eight", as Masuoka et al. (2007b) refer to them: “...exert powerful influence on the profession by directly or indirectly shaping the faculty who train the discipline as a whole....These eight departments may be said to self-dominate, in that a majority of the faculty in each of these departments comes from the set of eight. But, the graduates of these departments also constitute a majority of the faculty at 32 other departments. Thus, these eight departments produce a majority of faculty at 40 departments-a rather strong indicator of how pervasive their influence is" (p. 364). Kaba (2011c) finds out in his study of four Ivy League political science departments (Harvard, Penn, Princeton and Yale) that as of October 2005, of the 210 professors, $198(94.3 \%)$ had data for institution of terminal degree attainment. Of the 198 with terminal degree data available, 90 (45.4\%) were graduates of Ivy League universities. (Note 5)

The small group of contributors to the APSR from outside of the United States are mostly from Europe, with the United Kingdom having a very visible presence. Kaba's (2011c) study of four Ivy League political science departments mentioned above shows that: "Europe is the only continent apart from North America, whose universities sent graduates to teach at these four institutions, 18 (9.1\%) [out of 198], with the majority of them from the United Kingdom (Oxford University has 7 or 3.5\% of total)." (Note 6) Sigelman's (2006) article on contributors to the APSR in the 20th century shows that apart from North America, especially the United States, Europe is the only other region or continent that received attention in the journal, or with scholars who have had visible presence as authors in the pages of the journal. This is especially the case with the United Kingdom:

"Other than the United States, major attention was devoted only to Britain, any, and the other nations of Western Europe, which appeared in $27 \%$ and $18 \%$ of the Review's articles during its first and second decades. Other major powers, for example, Russia, Japan, and China, were accorded scant attention, and the rest of the world was virtually ignored....Even Britain, which ranked second over the entire century, was featured in just 96 articles, nowhere near the United States' 1,108....During the Review's first century, China and India, the world's most populous nations, were the subjects of about one Review article apiece every 5 or 6 years. Even the United States' nearest neighbors, Canada (18) and Mexico (12), received scant coverage" (p. 470).

An important factor for the dominance of the political science discipline, including the pages of the APSR by institutions in the United States and some others in Europe, especially in the United Kingdom, is money or massive amounts of endowments. The total endowment of an institution plays an important role in the prestige or reputation and success of an institution because they can afford to recruit top faculty and invest in the most modern scientific instruments needed for teaching and research. As of 2007, the endowments of the following institutions with $\$ 3$ billion or more are as follow: Harvard University, \$34.634 billion; Yale University, \$22.53 billion; Stanford University, $\$ 17.2$ billion; Princeton University, 15.8 billion; University of Texas System, $\$ 15.6$ billion; Massachusetts Institute of Technology, $\$ 9.9$ billion; Columbia University, $\$ 7.15$ billion; University of Michigan, \$7.1 billion; University of Pennsylvania, \$6.64 billion; Texas A \& M System, \$6.59 billion; Northwestern University, $\$ 6.5$ billion; University of California System, $\$ 6.44$ billion; University of Chicago, $\$ 6.2$ billion; University of Notre Dame, $\$ 5.98$ billion; Duke University, $\$ 5.9$ billion; Washington University in St. Louis, $\$ 5.57$ billion; Emory University, $\$ 5.56$ billion; Cornell University, $\$ 5.4$ billion; Rice University, $\$ 4.7$ billion; University of Virginia, $\$ 4.37$ billion; Dartmouth College, $\$ 3.76$ billion; University of Southern California, $\$ 3.72$ billion; and Vanderbilt University, $\$ 3.49$ billion. In Europe, the University of Cambridge and the University of Oxford in the United Kingdom are reported to have endowments of 4.1 billion British Pounds in November 2006, and 3.4 billion British Pounds in 2007, respectively (Kaba, 2012a, pp. 27-29).

The over century long relationship between the disciplines of political science and economics is observed in the data presented in this study. For example, of the 79 contributors, $93.7 \%$ of them are employed in Political Science/Government and related departments and $6.3 \%$ are employed in economics departments. Of the 79 contributors with degree attainment data, $88.6 \%$ are in Political Science/Government, $10.1 \%$ in economics and 
$1.3 \%$ in Math. Willoughby (1904) discussed this relationship between the disciplines of economics and political science:

"The connection between economics and politics is, if anything, more intimate. Without the information that the study of economic principles and of economic history affords, the political scientist is unable either to explain many of the processes of political growth or wisely to determine lines of public policy. Upon the other hand, deprived of the knowledge furnished by the scientific study of the mechanism and methods of operation of governments, the economist finds himself insufficiently informed either correctly to analyze past and existing economic conditions or satisfactorily to devise the means by which the truths that he discovers may be made of practical advantage to mankind" (p. 107).

The findings that stand out the most are those of the underrepresentation of women and minorities (Blacks in particular) among contributors of full-length articles to the APSR in 2010 and the political science discipline in general. The issue of the underrepresentation of Blacks is easily explained because of their experience with slavery in the United States and the entire Americas and Asia, and colonialism in Africa and their legacies (Kaba, 2013c). In the United States, this is especially the case with the close connection between the political science discipline and the politics of the country. One can then understand why Blacks are just as underrepresented in the discipline as they are in the political system of the United States. By 2012, there was not a single Black person in the United States Senate, with 100 members even though Blacks account for over 13\% of the population of 312 in 2012 (Kaba, 2012b).

Although by February 2013, there are two Black males in the United States Senate, they are both appointed by the Governors of South Carolina (Nikki Randhawa Haley appointed Tim Scott) and Massachusetts (Deval Laurdine Patrick appointed Paul G. Kirk) and they may face serious challenges if they decide to run for a full term. Other factors have been cited for the underrepresentation of Blacks among contributors to the APSR and in the political science discipline. Some of these factors are similar to the ones given for the underrepresentation of women in the discipline that we shall examine soon. The factors for the underrepresentation of Blacks include: lack of mentoring; human capital and social capital; work environment; lack of promotion, including tenure; Gender; and co-authorship (Alex-Assensoh et al., 2005; Ards et al., 1997; Evans, 2007; Fisher et al., 1998; Harley, 2008; Hesli \& Lee, 2011; Kaba, 2013c; Lopez, 2003; Sampaio, 2006).

Hesli and Lee (2011) point out that: “... questions are sometimes raised about whether an individual's status as a minority within academia (e.g., being a member of an underrepresented ethnic or racial group...) affects his or her ability to publish or likelihood of publishing ..." (p. 339). Lopez (2003) notes that: "Racial and ethnic minorities are not well represented in the social sciences and particularly in political science if one compares these figures to their White counterparts ..." (p. 837). Alex-Assensoh et al. (2005) point out that: "Given the nature of the academy, we believe an important element for success [of Black Americans] is effective mentoring.... Within the political science profession, African Americans continue to be underrepresented in the vast majority of predominantly white colleges and universities.... Rarely will one find more than one or two (if any) African Americans in political science departments on white campuses. We emphasize this point because the lack of faculty diversity is not only an issue of recruitment, but also of retention. Mentoring is a process that can increase the retention of Black faculty" (p. 283). According to Ards et al. (1997): "Gender may be a factor affecting the apparent relationship between race and rank. Studies show that women receive lower salary and rank and are less likely to be tenured than men..." (163).

Pertaining to the persistence of the small number of women among contributors to the APSR and also their underrepresentation within the political science discipline, many factors have been cited to explain this problem. Among the factors cited for the underrepresentation of women among contributors to the APSR and the discipline are: human capital; social capital; marriage, children or family formation; work environment; access to elite networks in the discipline; co-authorship; citations; hesitation by female scholars to submit research to top journals, including the APSR; less focus on women in the political science curriculum; gender differences in research methodologies used; women leaving the profession; fewer women on journal editorial boards; lower salaries for women; women are less likely to be promoted compared with men; gender stereotypes; and women teach more courses per year, and do more advising and mentoring than their male counterparts (Brandes et al., 2001; Breuning \& Sanders, 2007; Cassese et al., 2013; Grofman, 2009, p. 722; Fisher et al., 1998; Hesli et al., 2012; Hesli \& Lee, 2011; Mann, 1998; Marshall \& Rothgeb, Jr., 2011; Sampaio, 2006; Stegmaier et al., 2011; Young, 1995). 
Publishing scholarly articles in peer reviewed journals, has been examined from the point of view of gender, including that women publish fewer articles than men. One argument is that because female scholars do more teaching, advising and mentoring students than their male counterparts, it results in fewer publications. According to Young (1995): "Women's research and publication efforts have not been as thoroughly studied as their professional activities. Several conclusions, however, have been offered. ... female political scientists were less likely than male political scientists to conduct research and publish.... even when women publish in political science journals, their articles are unlikely to be cited by male colleagues. The sad conclusion is, because women publish less frequently and because men are unlikely to cite female-authored articles, few women are perceived to be top researchers in the field ..." (pp. 525-526). Hesli and Lee (2011) point out that: "A finding that we think particularly important to a profession that places a great deal of emphasis on publications when evaluating faculty performance is the negative effect of a heavy teaching load on research output. The opportunity costs of teaching a large number of courses and preparing new courses are significant indeed. Thus, our findings correspond to the findings of many other scholars--that time spent teaching takes away from time spent doing research" (p. 402). Hesli and Lee (2011) also add that: "Another explanation that has been offered in the literature is that women spend more time "mentoring" than do male faculty.... women are more likely than men to devote time to teaching and advising..." (pp. 400 \& 402). According to Mann's (1998) study: "Nearly comparable percentages of the newly employed undergraduate faculty identified teaching and scholarship as important attributes. Among undergraduate faculty, higher percentages of men (41\%) than women (33\%) said scholarship was the most important attribute and higher percentages of women (42\%) than men said teaching was the most important attribute (32\%)" (p. 603).

Women, like minorities have also been put into a situation where they are encouraged to co-author articles or co-publish articles with White male scholars, but this could also lead people to question whether they made any significant contribution to such published work. Alex-Assensoh et al. (2005) suggest that: "Senior non-black faculty members should make sincere efforts to involve faculty of color, including in research collaborations. This will help promote collegiality and provide opportunities for increasing publication" (p. 285). According to Fisher et al. (1998):

"In this regard, it is noteworthy that among women in the social sciences, but particularly among women in political science, the dominant form of authorship has become cross-sex collaborations. Just over half of the articles published by women in the leading journals resulted from cross-sex collaborations. In contrast, men appear more likely to author articles on their own or to coauthor articles with other men. The pervasiveness of female scholars collaborating with males again raises the issue of how multiple-authored articles should be evaluated. If these works are devalued, or if women's contributions are implicitly attributed to male coauthors, then the high level of multiple authorship among females may help to produce social (e.g., professional recognition, promotion) and economic (e.g., salary, merit pay) inequality within academia" (p. 854; also see pp. 847-848).

Marriage and family formation, including having children have been cited as contributing factors for the underrepresentation of women in the profession. Hesli and Lee (2011) point out that: “... women spend more time than their male colleagues on household and childcare responsibilities..." (p. 402). According to Hesli et al. (2012):“ “. . because of the need to earn tenure within a set time, 'academic careers may be exceptionally demanding during the family formation phase of life' ...for men, having children has a positive effect on promotion, although for women, children have a negative effect on promotion.... Being married (with or without children) may affect the likelihood of being promoted..., although the effect is likely to be different for men and women" (p. 477).

It has been noted that Social Capital is a contributing factor for the gender disparities within the political science discipline: "Social capital theories argue that the resources needed to obtain tenure and promotion, such as 'information and knowledge about institutional norms, expectations, and opportunities; access to and influence on key decision makers; certification and endorsement of an individual's qualifications; and emotional support and recognition' are less available to women than to men because women lack access to the collegial and social networks that convey critical job-related knowledge.... Networks are important at tenure time because they can result in more adulatory outside reference letters" (Hesli et al., 2012, p. 477).

It has also been noted that within academia, especially in the professoriate, women tend to experience "consensual status hierarchies", but this is also the case for minorities. The hierarchy in promotion from assistant professor to associate professor with or without tenure, and then to full professor, makes this "consensual status 
hierarchies" become entrenched. This then results in persistent emphasis in male leadership, just as in the general society. Hesli et al. (2012) point out that:

"More subtle cognitive processes may also operate to favor in-groups and disfavor out-groups.... Rather than experiencing overt discrimination in the workplace, out-groups encounter "consensual status hierarchies" that operate structurally to produce inequality .... Such processes, which perpetuate inequalities, persist not because of conscious efforts, but because individual actions 'are complicit with previously established norms'... Social psychologists assert that common stereotypes about gender differences in a larger society (a hierarchy of gender status beliefs) are reproduced within organizations such as universities--and important consequences follow, such as differential access to resources and decisions about competence... Because academic judgments of the quality of a colleague's work are inherently subjective, the tendency of evaluators is to fall back on existing schema, stereotypes, and personal biases .... Sexism in peer review may be a more overt manifestation of such processes... Other examples of subtle or unconscious discrimination include encouragement of early promotion for men but not for women, more impressive language used to describe the records of men than for women, and promotion to senior professor largely on the basis of departmental administrative needs for men but not for women ..." (p. 477).

According to Cassese et al. (2012):

"The emphasis on male leadership and power in the mainstream curriculum belies the political relevance of gender. The absence of explicit references to women and gender politics implicitly signals to students its lack of importance or centrality to the study of political life and political processes. This notion--the absence of certain content is as relevant as the inclusion of particular content--is captured in the concept of the "hidden curriculum" .... In political science, the hidden curriculum reinforces stereotypes about gender, status, and power. It bolsters the association between men and agentic leadership traits and between women and more communal, submissive traits, all of which directly bears on attitudes toward political leadership... Furthermore, it fails to situate female majors within their own field of study, instead sending a powerful implicit signal about minority status within the discipline--a signal reinforced by the absence of female faculty ..." (pp. 239-240).

It has been pointed out that because women are less likely to enroll for their bachelor's degrees in political science and that fewer of them also enroll in political science graduate programs, it results in their underrepresentation in the field, including among faculty members: "In turn, the lack of female faculty members translates to a lack of female role models and mentors for female majors who would consider pursuing graduate studies. It may also result in fewer elective course offerings in gender politics and less coverage of gender-relevant material across all course offerings" (Cassese et al., 2012, p. 239).

Finally, Stegmaier et al. (2011) present a number of factors, with some already noted above for the underrepresentation of women in the political science discipline, including as contributors to the APSR:

"First, there is a "leaking pipeline"; women are leaving the profession for alternative careers. Second, for women trying to balance work and family, childbearing years typically correspond with the heavy academic demands associated with tenure and promotion. This can make it difficult for parents to meet the research expectations for tenure, which results in some women leaving academia and others being denied tenure and promotion. Third, the institutional climate is often "inhospitable" to women, failing to provide the mentoring and support needed for women to succeed in the profession. Finally, a culture of research continues to provide maximum reward for single-authorship rather than collaborative research.... These forces combined stagnate the progress made by women, particularly at the senior levels" (p. 799).

This study began with an explanation of the importance of publishing scholarly articles in peer reviewed journals, especially in the APSR, in the case of political scientists and social scientists. It shows that publishing articles in such journals can result in employment as a faculty member, and an opportunity to earn tenure and promotion to associate and full professors. It can also contribute to one's chances of getting research grants.

Among the findings in this study are that: over 4 out of every 5 contributors of full-length articles to the APSR in 2010 are males; Whites accounted for over 9 out of every 10 contributors; Full professors accounted for $35 \%$, the highest rate, with assistant professors accounting for 31 percent; Yale University, Harvard University, University of Illinois-Champaign, Florida State University, Massachusetts Institute of Technology, University of 
California-San Diego, and the University of Chicago, all employ 3 or more of these contributors; over 8 out of every 10 contributors are employed in a political science/government department alone; almost $94 \%$ of the contributors have a Ph.D.; almost $89 \%$ of the contributors earned their terminal or highest degrees in political science/government; Harvard University, the University of Chicago, the University of Rochester, the University of California-Berkeley, and Duke University, all conferred 4 or more terminal or highest degrees to these contributors; and all of the contributors earned their terminal or highest degrees from 1968-2011.

The study goes on to explain or make sense of the findings, including the dominance of the APSR and the discipline by a selected number of institutions in the United States and Europe, and the issue of the underrepresentation of women and minorities. Among the factors cited for the underrepresentation of women are: marriage, children or family formation, co-authorship, work environment, fewer women on journal editorial boards; lower salaries for women; differences in research methodologies; and teaching load for female faculty members.

\section{References}

Agarwala, R., \& Teitelbaum, E. (2010). Trends in Funding for Dissertation Field Research: Why Do Political Science and Sociology Students in So Few Awards. PS: Political Science \& Politics, 43(2), 283-293. http://dx.doi.org/10.1017/S1049096510000156

Alex-Assensoh, Y. M., Givens, T., Golden, K., Hutchings, V. L., Wallace, S. L., \& Whitby, K. J. (2005). Mentoring and African-American Political Scientists. PS, Political Science \& Politics, 38(2), 283-285. http://dx.doi.org/10.1017/S1049096505056490

Amir, R., \& Knauff, M. (2008). Ranking Economics Departments Worldwide on the Basis of PhD Placement. The Review of Economics and Statistics, 90(1), 185-190. http://dx.doi.org/10.1162/rest.90.1.185

Ards, S., Brintnall, M., \& Woodard, M. (1997). The Road to Tenure and Beyond for African American Political Scientists. Journal of Negro Education, 66(2), 159-171. http://dx.doi.org/10.2307/2967225

Ballard, M. J., \& Mitchell, N. J. (1998). The Good, the Better, and the Best in Political Science. PS, Political Science \& Politics, 31(4), 826-828. http://dx.doi.org/10.2307/420727

Boncourt, T. (2007). The Evolution of Political Science in France and Britain: A Comparative Study of Two Political Science Journals. European Political Science, 6(3), 276-294. http://dx.doi.org/10.1057/palgrave.eps.2210137

Brandes, L., Buker, E., Burgess, S., Cook, C., Flammang, J., Geiger, S., Okin, S., Yoon, B. S., \& Ackelsberg, M. (2001). The Status of Women in Political Science: Female Participation in the Professoriate and the Study of omen and Politics in the Discipline. PS, Political Science \& Politics, 34(2), 319-326.

Breuning, M., \& Sanders, K. (2007). Gender and Journal Authorship in Eight Prestigious Political Science Journals. PS, Political Science \& Politics, 40(2), 347-351. http://dx.doi.org/10.1017/S1049096507070564

Burchard, E. G., Borrell, L. N., Choudhry, S., Naqvi, M, Tsai, H. J., Rodriguez-Santana, J. R., ... Risch., N. (2005). Latino Populations: A Unique Opportunity for the Study of Race, Genetics, and Social Enironment in Epidemiologcal Research. American Journal of Public Health, 95(12), 2161-2168. http://dx.doi.org/10.2105/AJPH.2005.068668

Butler, D. M., Butler, R. J., \& Rich, J. T. (2008). The Equalizing Effect of the Internet on Access to Reserch Expertise in Political Science and Economics. PS, Political Science \& Politics, 41(3), 579-584. http://dx.doi.org/10.1017/S1049096508080785

Cassese, E. C., Bos, A. L., \& Duncan, L. E. (2012). Integrating Gender into the Political Science Core $\begin{array}{lllll}\text { Curriculum. } & P S, \quad \text { Political } & \text { Science } \& \quad \text { Politics, } & 45(2), & \text { 238-243. }\end{array}$ http://dx.doi.org/10.1017/S1049096512000042

De Rond, M., \& Miller, A. N. (2005). Publish or Perish. Journal of Management Inquiry, 14(4), 321-329. http://dx.doi.org/10.1177/1056492605276850

DiFuccia, M., Pelton, J., \& Sica, A. (2007). If and When Sociology Becomes a Female Preserve. American Sociologist, 38(1), 3-22. http://dx.doi.org/10.1007/s12108-007-9001-2

Dolan, J., Kropf, M. E., O’Connor, K., \& Ezra, M. (1997). The Future of Our Discipline: The Status of Doctoral Students in Political Science. PS, Political Science \& Politics, 30(4), 751-756. http://dx.doi.org/10.1007/s12108-007-9001-2 
Erne, R. (2007). On the Use and Abuse of Bibliometric Performance Indicators: A Critique of Hix's 'Global Ranking of Political Science Departments. European Political Science, 6(3), 306-314. http://dx.doi.org/10.1057/palgrave.eps.2210136

Evans, H. K., \& Moulder, A. (2011). Reflecting on Decade of Women's Publications in Four Top Political $\begin{array}{llllll}\text { Science Journals. PS, Political Science \& Politics, } & 44(4), \quad 793-798 .\end{array}$ http://dx.doi.org/10.1017/S1049096511001296

Evans, S. Y. (2007). Women of Color in American Higher Education. Thought \& Action, 23, 131-138.

Finifter, A. W. (1998). The 1997-98 Sail on the Flagship American Political Science Review. PS, Political Science \& Politics, 31(4), 897-905.

Fisher, B. S., Cabane, C. T., Vander, V., Thomas, M., \& Cullen, F. T. (1998). How Many Authors Does It Take to Publish an Article? Trends and Patterns in Political Science. PS, Political Science \& Politics, 31(4), 847-856. http://dx.doi.org/10.2307/420730

Fowler, J. H., Grofman, B., \& Masuoka, N. (2007). Social Networks in Political Science: Hiring and Placement of Ph.D.s, 1960-2002. PS, Political Science \& Politics, 40(4), $729-739$. http://dx.doi.org/10.1017/S104909650707117X

Gans, H. J. (2012). "Whitening” and the Changing American Racial Hierarchy. Du Bois Review, 9(2), 267-279. http://dx.doi.org/10.1017/S1742058X12000288

Garand, J. C., \& Giles, M. W. (2003). Journals in the Discipline: A Report on a New Survey of American Political Scientists. PS, Political Science \& Politics, 36(2), 293-308.

Garand, J. C., \& Giles, M. W., Blais, A., \& McLean, I. (2009). Political Science Journals in Comparative Perspective: Evaluating Scholarly Journals in the United States, Canada, and the United Kingdom. PS, Political Science \& Politics, 42(4), 695-717. http://dx.doi.org/10.1017/S1049096509990205

Garand, J. C., \& Graddy, K. L. (1999). Ranking Political Science Departments: Do Publications Matter. PS, Political Science \& Politics, 32(1), 113-116. http://dx.doi.org/10.2307/420759

Glazer, N. (2001). American diversity and the 2000 Census. Public Interest, 144, 3-18.

Grofman, B. (2009). Determinants of Political Science Faculty Salaries at the University of California. PS, Political Science \& Politics, 42(4), 719-727. http://dx.doi.org/10.1017/S1049096509990175

Harley, D. A. (2008). Maids of the Academy: African American Women Faculty at Predominantly White $\begin{array}{lllll}\text { Institutions. Journal of African American } & \text { Studies, } & 12(1), & 19-36 .\end{array}$ http://dx.doi.org/10.1007/s12111-007-9030-5

Heck, J. L. (1993). Eight Decades of Contributing Authors and Institutions to the American Economic Review: A Historical Summary. Journal of Economic Education, 24(2), 163-170. http://dx.doi.org/10.2307/1183164

Hesli, V. L. \& Lee, J. M. (2011). Faculty Research Productivity: Why Do Some of Our Colleagues Publish More than Others? PS: Political Science \& Politics, 44(2), 393-08.

Hesli, V. L., \& Lee, J. M. (2011). Faculty Research Productivity: Why Do Some of Our Colleagues Publish More than Others? PS: Political Science \& Politics, 44(2), 393-408.

Hesli, V. L., Lee, J. M., \& Mitchell, S. M. (2012). Predicting Rank Attainment in Political Science: What Else Besides Publications Affects Promotion? PS: Political Science \& Politics, 45(3), 475-492. http://dx.doi.org/10.1017/S1049096512000364

Hix, S. (2004). A Global Ranking of Political Science Departments. Political Studies Review, 2(3), 293-313. http://dx.doi.org/10.1017/S1049096512000364

Ishiyama, J., Miles, T., \& Balarezo, C. (2010). Training the Next Generation of Teaching Professors: A Comparative Study of Ph.D. Program in Political Science. PS, Political Science \& Politics, 43(3), 515-522. http://dx.doi.org/10.1017/S1049096512000364

Jacobs, J. A. (2005). ASR's Greatest Hits. American Sociological Review, 70(1), 1-3. http://dx.doi.org/10.1177/000312240507000101

Jacobs, J. A. (2007). Further Reflections on ASR's Greatest Hits. American Sociologist, 38(1), 99-131. http://dx.doi.org/10.1007/s12108-007-9003-0 
Kaba, A. J. (2008). Religion, Immigration and Assimilation: the Hispanic/Latino Population in the United States and the North African/Muslim Population in Europe. Asian Journal of Latin American Studies, 21(2), 69-102.

Kaba, A. J. (2010). Inheritance, Race and the Four Major Factors for the Unity Between African Americans and European Americans: Land/Territory, Blood/Genes, Religion and Language. African Renaissance, 7(2), 93-106

Kaba, A. J. (2011a). African Americans in the National Basketball Association (NBA), 2005-2006: Demography and Earnings. International Journal of Social and Management Sciences, 4(1), 1-25.

Kaba, A. J. (2011b). The Family and Political Unity between Blacks and Jews in the United States. International Journal of Humanities and Social Science, 1(21), 167-177.

Kaba, A. J. (2011c, June 29). Demographics and Publication Productivity of Ivy League Political Science Professors: Harvard, Princeton, University of Pennsylvania and Yale. Holler Africa Magazine. Retrieved February 3, 2013, from: http://www.hollerafrica.com/showArticle.php?catId=5\&artId=484

Kaba, A. J. (2012a). Analyzing the Anglo-American hegemony in the Times Higher Education Rankings. Education Policy Analysis Archives, 20(21), 1-53.

Kaba, A. J. (2012b). The Exclusion of Black Women from National Leadership Positions in the United States: Taxation with Limited Representation. Sociology Mind, 2(2), 133-140. http://dx.doi.org/10.4236/sm.2012.22017

Kaba, A. J. (2013a). Profile of Contributors to the American Economic Review, 2010: Human Capital Theory, Gender and Race (Book Manuscript, 140 pages).

Kaba, A. J. (2013b). Profile of Contributors to the American Sociological Review, 2010 (69 pages, Under Review).

Kaba, A. J. (2013c). Black Americans, Gains in Science and Engineering Degrees, and Gender. Sociology Mind, 3(1), 67-82. http://dx.doi.org/10.4236/sm.2013.31012

Katz, R. S., \& Eagles, M. (1996). Ranking Political Science Programs: A View from the Lower Half. PS, Political Science \& Politics, 29(2), 149 (5 pages). http://dx.doi.org/10.2307/420692

Lopez, L. (2003). Placement Report: Political Science Ph.D.s and ABD on Job Market in 2001-2002. Political Science \& Politics, 36(4), 835-841.

Losco, J. (1998). Whither Intellectual Diversity in American Political Science? The Case of APSA and Organized Sections. PS, Political Science \& Politics, 31(4), 836-846. http://dx.doi.org/10.2307/420729

Lowry, R. C., \& Silver, B. D. (1996). A Rising Tide Lifts all Boats: Political Science Department Reputation and the Reputation of the University. PS, Political Science \& Politics, 29(2), 161 (6 pages). http://dx.doi.org/10.2307/420694

Mann, S. (1998). Finding Jobs in Political Science: 1996 Placement Candidates Report on Their Employment Search and Outcomes. Political Science \& Politics, 31(3), 591-608. http://dx.doi.org/10.2307/420622

Marshall, B. W., \& Rothgeb, J. Jr. (2011). So You Want Tenure? Factors Affecting Tenure Decisions in Politicl $\begin{array}{llllll}\text { Science Departments. PS, Political Science \& Politics, } & 44(3), & \text { 571-577. }\end{array}$ http://dx.doi.org/10.1017/S1049096511000680

Masuoka, N., Grofman, B., \& Feld, S. L. (2007a). Ranking Departments: A Comprison of Alternative $\begin{array}{lllll}\text { Approaches. } & P S, \quad \text { Political Science \& } & \text { Politics, } & 40(3), & \text { 531-537. }\end{array}$ http://dx.doi.org/10.1017/S1049096507070825

Masuoka, N., Grofman, B., \& Feld, S. L. (2007b). The Production and Placement of Political Science Ph.D.s, 1902-2000. PS, Political Science \& Politics, 40(2), 361-366. http://dx.doi.org/10.1017/S1049096507070576

McCormick, J. M., \& Rice, T. W. (2001). Graduate Training and Research Productivity in the 1990s: A Look at Who Publishes. PS, Political Science \& Politics, 34(3), 675-680. http://dx.doi.org/10.1017/S1049096501001081

Miller, A. H., \& Tien, C. (1996). The American Political Science Review Hall of Fame: Assessment And Implications for an Evolving Discipline. PS, Political Science \& Politics, 29(1), 73-83. http://dx.doi.org/10.2307/420198 
Morning, A. (2000). Who Is Multiracial? Definitions and Decisions. Sociological Imagination, 37(4), 209-229

Morning, A. (2005). Multiracial Classification on the United States Census: Myth, Reality, and Future Impact. Revue Européenne des Migrations Internationales, 21(2), 111-134. http://dx.doi.org/10.4000/remi.2495

Nelson, D., \& Brammer, C. N. (2010, January 4). A National Analysis of Minorities in Science and Engineering Faculties at Research Universities (2nd ed.). Retrieved December 27, 2012, from http://faculty-staff.ou.edu/N/Donna.J.Nelson-1/diversity/Faculty_Tables_FY07/07Report.pdf

Oprisko, R. (2012, December 3). Superpowers: The American Academic Elite. Georgetown Public Policy Review. Retrieved January 25, 2013, from http://gppreview.com/2012/12/03/superpowers-the-american-academic-elite/

Paxton, P., \& Bollen, K. A. (2003). Perceived Quality and Methodology in Graduate Department Ratings: Sociology, Political Science, and Economics. Sociology of Education, 76(1), 71-88. http://dx.doi.org/10.2307/3090262

Plümper, T. (2007). Academic Heavy-weights: The 'Relevance' of Political Science Journals. European Political Science, 6(1), 41-50. http://dx.doi.org/10.1057/palgrave.eps.2210112

Political Science Ranked in 2009. (2013). U.S. News and World Report. Retrieved March 3, 2013, from http://grad-schools.usnews.rankingsandreviews.com/best-graduate-schools/top-humanitie

Polsky, A. J. (2007). Seeing Your Name in Print: Unpacking the Mysteries of the Review Process at Political Science Scholarly Journals. PS, Political Science \& Politics, 40(3), 539-543. http://dx.doi.org/10.1017/S1049096507070801

Price, G. N. (2009). The Problem of the 21st Century: Economics Faculty and the Color Line. Journal of Socio-Economics, 38(2), 331-343. http://dx.doi.org/10.1016/j.socec.2008.10.007

Rogowski, R. (2012). Annul Report of the Editors of the American Political Science Review. PS, Political Science \& Politics, 45(2), 327-329. http://dx.doi.org/10.1017/S1049096512000121

Rothgeb, J. M., \& Burger. (2009). Tenure Standards in Political Science Departments: Results from a Survey of

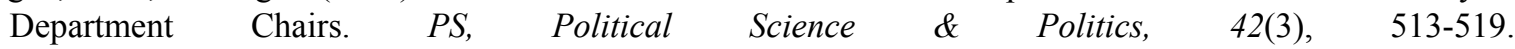
http://dx.doi.org/10.1017/S1049096509090829

Sampaio, A. (2006). Women of Color Teaching Political Science: Examining the Intersections of Race, Gender, and Course Material in the Classroom. PS, Political Science \& Politics, 39(4), 917-922. http://dx.doi.org/10.1017/S1049096506061191

Schmidt, B. M., \& Chingos, M. M. (2007). Ranking Doctoral Programs by Placement: A New Method. PS, Political Science \& Politics, 40(3), 523-529. http://dx.doi.org/10.1017/S1049096507070771

Sigelman, L. (2006). The Coevolution of American Political Science and the American Political Science Review. American Political Science Review, 100(4), 463-478. http://dx.doi.org/10.1017/S0003055406062319

Stegmaier, M., Palmer, B., \& Van Assendelft, L. (2011). Getting on the Board: The Presence of Women in Political Science Journal Editorial Positions. PS, Political Science \& Politics, 44(4), 799-804. http://dx.doi.org/10.1017/S1049096511001284

Tang, T. L. P., \& Chamberlain, M. (2003). Effects of Rank, Tenure, Length of Service, and Institution on Faculty Attitudes Toward Research and Teaching: The Case of Regional State Universities. Journal of Education for Business, 79(2), 103-110. http://dx.doi.org/10.1080/08832320309599097

Willoughby, W. W. (1904). The American Political Science Association. Political Science Quarterly, XIX(1), 107-111. http://dx.doi.org/10.2307/2140238

Yancey, G. (2003). Who is White: Latinos, Asians, and the New Black/Nonblack Divide. Boulder, CO: Lynne Rienner Publishers.

Young, C. D. (1995). An Assessment of Articles Published by Women in Top 15 Political Science Journals. PS, Political Science \& Politics, 28(3), 525 (5 pages). http://dx.doi.org/10.2307/420325

\section{Appendices}

Appendix A

Regional Breakdown of the United States $(\mathrm{N}=51)$

Northeast $(\mathbf{n}=9)$ 
Connecticut, Maine, Massachusetts, New Hampshire, New Jersey, New York, Pennsylvania, Rhode Island, Vermont.

\section{Midwest (n=12)}

Illinois, Indiana, Iowa, Kansas, Michigan, Minnesota, Missouri, Nebraska, North, Dakota, Ohio, South Dakota, Wisconsin.

South (n=17)

Alabama, Arkansas, Delaware, District of Columbia, Florida, Georgia, Kentucky, Louisiana, Maryland, Mississippi, North Carolina, Oklahoma, South Carolina, Tennessee, Texas, Virginia,West Virginia.

West $(\mathbf{n}=13)$

Alaska, Arizona, California, Colorado, Hawaii, Idaho, Montana, Nevada, New Mexico, Oregon, Utah, Washington, Wyoming.

Source: "Summary Social, Economic, and Housing Characteristics: 2000 Census of Population and Housing," (2003, June). Selected Appendixes: 2000. PHC-2-A. Washington, D.C.: U.S. Census Bureau.

Appendix $B$

Composition of macro geographical (continental) regions, geographical sub-regions, and selected economic and other groupings Nations, Territories and Entities plus Taiwan $(\mathbf{N}=\mathbf{2 3 8})$

Africa (n=57)

Eastern Africa (n=19)

Burundi, Comoros, Djibouti, Eritrea, Ethiopia, Kenya, Madagascar, Malawi, Mauritius, Mozambique, Reunion, Rwanda, Seychelles, Somalia, Tanzania, Uganda, Zambia, Zimbabwe and Mayotte.

Middle Africa (n=9)

Angola, Cameroon, Central African Republic, Chad, Republic of Congo, Democratic Republic of Congo, Equatorial Guinea, Gabon and Sao Tome \& Principe

Northern Africa ( $n=7)$

Algeria, Egypt, Libya, Morocco, Sudan, Tunisia and Western Sahara

Southern Africa (n=5)

Botswana, Lesotho, Namibia, South Africa and Swaziland

Western Africa (n=17)

Benin, Burkina Faso, Cape Verde, Cote d'Ivoire, The Gambia, Ghana, Guinea, Guinea-Bissau, Liberia, Mali, Mauritania, Niger, Nigeria, Senegal, Sierra Leone, Togo and Saint Helena.

\section{Americas $\mathbf{N}=\mathbf{5 3}$}

Latin America and the Caribbean $(n=48)$

\section{Caribbean $(\mathrm{n}=\mathbf{2 6})$}

Anguilla, Antigua and Barbuda, Aruba, Bahamas, Barbados, British Virgin Islands, Cayman Islands, Cuba, Dominica, Dominican Republic, Grenada, Guadeloupe, Haiti, Jamaica, Martinique, Montserrat, Netherlands Antilles, Puerto Rico, Saint-Barthélemy, Saint Kitts and Nevis, Saint Lucia, Saint Martin (French part), Saint Vincent and the Grenadines, Trinidad and Tobago, Turks and Caicos Islands, United States Virgin Islands,

\section{Central America $(n=8)$}

Belize, Costa Rica, El Salvador, Guatemala, Honduras, Mexico, Nicaragua, Panama

\section{South America $(n=14)$}

Argentina, Bolivia (Plurinational State of), Brazil, Chile, Colombia, Ecuador, Falkland Islands (Malvinas), French Guiana, Guyana, Paraguay, Peru, Suriname, Uruguay, Venezuela (Bolivarian Republic of).

\section{Northern America $(\mathbf{n}=5)$}

Bermuda, Canada, Greenland, Saint Pierre and Miquelon, United States of America

Asia (N=51)

Central Asia (n=5) 
Kazakhstan, Kyrgyzstan, Tajikistan, Turkmenistan, Uzbekistan

\section{Eastern Asia (n=8)}

China, Hong Kong Special Administrative Region of China, Macao Special Administrative Region of China, Democratic People's Republic of Korea, Japan, Mongolia, Republic of Korea, Taiwan* (As noted in the methodology, I added Taiwan to Eastern Asia)

\section{Southern Asia (n=9)}

Afghanistan, Bangladesh, Bhutan, India, Iran (Islamic Republic of), Maldives, Nepal, Pakistan, Sri Lanka

\section{South-Eastern Asia (n=11)}

Brunei Darussalam, Cambodia, Indonesia, Lao People's Democratic Republic, Malaysia, Myanmar, Philippines, Singapore, Thailand, Timor-Leste, Viet Nam

\section{Western Asia (n=18)}

Armenia, Azerbaijan, Bahrain, Cyprus, Georgia, Iraq, Israel, Jordan, Kuwait, Lebanon, Occupied Palestinian Territory (Gaza and the West Bank), Oman, Qatar, Saudi Arabia, Syrian Arab Republic, Turkey, United Arab Emirates, Yemen.

\section{Europe ( $\mathbf{N}=\mathbf{5 2})$}

\section{Eastern Europe $(\mathbf{n}=\mathbf{1 0})$}

Belarus, Bulgaria, Czech Republic, Hungary, Poland, Republic of Moldova, Romania, Russian Federation, Slovakia, Ukraine.

\section{Northern Europe ( $\mathrm{n}=17)$}

Åland Islands, Channel Islands, Denmark, Estonia, Faeroe Islands, Finland, Guernsey, Iceland,

Ireland, Isle of Man, Jersey, Latvia, Lithuania, Norway, Svalbard and Jan Mayen Islands, Sweden,

United Kingdom of Great Britain and Northern Ireland

\section{Southern Europe $(\mathbf{n}=16)$}

Albania, Andorra, Bosnia and Herzegovina, Croatia, Gibraltar, Greece, Holy See, Italy, Malta, Montenegro, Portugal, San Marino, Serbia, Slovenia, Spain, The former Yugoslav Republic of Macedonia.

\section{Western Europe ( $n=9)$}

Austria, Belgium, France, Germany, Liechtenstein, Luxembourg, Monaco, Netherlands, Switzerland.

\section{Oceania $(\mathbf{N}=\mathbf{2 5})$}

\section{Australia and New Zealand ( $=3$ )}

Australia, New Zealand, Norfolk Island.

\section{Melanesia (n=5)}

Fiji, New Caledonia, Papua New Guinea, Solomon Islands, Vanuatu.

\section{Micronesia $(n=7)$}

Guam, Kiribati, Marshall Islands, Micronesia (Federated States of), Nauru, Northern Mariana Islands, Palau

\section{Polynesia (10)}

American Samoa, Cook Islands, French Polynesia, Niue, Pitcairn, Samoa, Tokelau, Tonga, Tuvalu, Wallis and Futuna Islands

Source: "Composition of macro geographical (continental) regions, geographical sub-regions, and selected economic and other groupings" Retrieved on November 15, 2009 from: http://unstats.un.org/unsd/methods/m49/m49regin.htm.

\section{Notes}

Note 1. "Table 22. Doctorate Recipients, by Citizenship, Race/Ethnicity, and Subfield of "Table 22. Doctorate Recipients, by Citizenship, Race/Ethnicity, and Subfield of Study: 2011,” 2012. Doctorate Recipients from U.S. Universities: 2011. Retrieved on December 15, 2012 from: http://www.nsf.gov/statistics/sed/2011/data_table.cfm. 
Note 2. "Political Science Ranked in 2009," 2013. U.S. News and World Report. Retrieved on March 3, 2013 from: http:/grad-schools.usnews.rankingsandreviews.com/best-graduate-schools/top-humanitie

s-schools/political-science-rankings.

Note 3. Kaba, Amadu Jacky. 2011c, June 29. "Demographics and Publication Productivity of Ivy League Political Science Professors: Harvard, Princeton, University of Pennsylvania and Yale,” Holler Africa Magazine. Retrieved on February 3, 2013 from: http://www.hollerafrica.com/showArticle.php?catId=5\&artId=484.

Note 4. Oprisko, Robert. 2012, December 3. "Superpowers: The American Academic Elite," Georgetown Public Policy Review. Retrieved on January 25, 2013 from: http://gppreview.com/2012/12/03/superpowers-the-american-academic-elite/.

Note 5. Kaba, Amadu Jacky. 2011, June 29. “Demographics and Publication Productivity of Ivy League Political Science Professors: Harvard, Princeton, University of Pennsylvania and Yale," Holler Africa Magazine. Retrieved on February 3, 2013 from: http://www.hollerafrica.com/showArticle.php?catId=5\&artId=484.

Note 6. Kaba, Amadu Jacky. 2011, June 29. "Demographics and Publication Productivity of Ivy League Political Science Professors: Harvard, Princeton, University of Pennsylvania and Yale," Holler Africa Magazine. Retrieved on February 3, 2013 from: http://www.hollerafrica.com/showArticle.php?catId=5\&artId=484.

\section{Copyrights}

Copyright for this article is retained by the author(s), with first publication rights granted to the journal.

This is an open-access article distributed under the terms and conditions of the Creative Commons Attribution license (http://creativecommons.org/licenses/by/3.0/). 